\title{
Decomposition of Austenite in Austenitic Stainless Steels
}

\author{
A. F. PADILHA and P. R. RIOS ${ }^{1)}$
}

Universidade de São Paulo, Departamento de Engenharia Metalúrgica e de Materiais, Av. Prof. Mello Moraes, 2463, São Paulo, 05508-900 Brazil. E-mail: padilha@usp.br 1) Universidade Federal Fluminense, Escola de Engenharia Industrial Metalúrgica de Volta Redonda, Av. dos Trabalhadores, 420, Volta Redonda, RJ, 27255-125 Brazil.

(Received on November 19, 2001; accepted in final form on January 18, 2002)

\begin{abstract}
Austenitic stainless steels are probably the most important class of corrosion resistant metallic materials. In order to attain their good corrosion properties they rely essentially on two factors: a high chromium content that is responsible for the protective oxide film layer and a high nickel content that is responsible for the steel to remain austenitic. Thus the base composition is normally a Fe-Cr-Ni alloy. In practice the situation is much more complex with several other elements being present, such as, Mo, Mn, C, N among others. In such a complex situation one almost never has a single austenite phase but other phases invariably form. Those phases are, with few exceptions, undesirable and they can be detrimental to the corrosion and mechanical properties. It is therefore of considerable importance to study the formation of such phases. In this work the decomposition of austenite in austenitic stainless steels is reviewed in detail. First the binary equilibrium diagrams relevant to the system $\mathrm{Fe}-\mathrm{Cr}-\mathrm{Ni}$ are briefly presented as well as other diagrams, such as the Schaeffler diagram, that traditionally have been used to predict the phases present in these steels as a function of composition. Secondly the precipitation of carbides and intermetallic phases is presented in detail including nucleation sites and orientation relationships and the influence of several factors such as composition, previous deformation and solution annealing temperature. Next, the occurrence of other constituents such as nitrides, sulfides and borides is discussed. TTT diagrams are also briefly presented. Finally the formation of martensite in these steels is discussed.
\end{abstract}

KEY WORDS: austenitic stainless steel; precipitation behaviour; carbides; intermetallic compounds; TTT diagram; strain induced martensite.

\section{Introduction}

Austenitic stainless steels were invented in Essen, Germany, in the beginning of the 20th century. ${ }^{1)}$ Their continuing development has resulted in complex steel compositions with substantial amounts of alloying elements. These alloying elements are of course introduced in the steel for one or more reasons but the final aim is mainly to obtain better mechanical properties and/or higher corrosion resistance. As usual the benefits of such additions invariably come attached to unavoidable disadvantages of which the most important is the potential microstructural instability of the material. Already during solidification or afterwards during thermomechanical processing and high temperature service a significant number of alloy phases or compounds can form. Even close to room temperature one might still have an unstable microstructure as the formation of strain induced martensite may occur. In the majority of the cases the formation of such phases is undesirable so that careful processing is needed to avoid or to minimize them.

Stainless steel plays an important role in the modern world, even if its tonnage represents only about $2 \%$ of the whole steel products. Austenitic stainless steels represent more than $2 / 3$ of the total stainless steel world production. Table 1 shows the standard compositions of common austenitic stainless steels classified according to the American Iron and Steel Institute (AISI). Other non-standard austenitic stainless steels will be mentioned later. More than half of the austenitic stainless steels used are types AISI 304 and 316 and their low carbon compositions: AISI 304L and 316L. Types AISI 321 and 347, titanium and niobium stabilized, respectively, are also often employed. These four types, due to their foremost practical importance will receive special attention in this review.

Table 1 shows the main alloying elements and their corresponding composition ranges. In addition to iron, the main components are $\mathrm{Cr}$ to improve corrosion resistance and $\mathrm{Ni}$ to stabilize austenite. Chromium contents range from 15 to $26 \mathrm{wt} \%$ and nickel contents from 5 to $37 \mathrm{wt} \%$. The 200 series have a lower Ni content than the 300 series. These steels have a high Mn content up to $15.5 \mathrm{wt} \%$ and also a high $\mathrm{N}$ content that partly replaces $\mathrm{Ni}$ as austenite stabilizers. In some steels one can find 2 to $4 \mathrm{wt} \%$ of molybdenum. Mo is primarily introduced to improve the resistance against pitting corrosion but it is also efficient in promoting solid solution hardening. More recently developed steels, known as superaustenitic stainless steels, can contain up to $6 \mathrm{wt} \%$ Mo. The term superaustenitic relates to austenitic stainless steels containing high amounts of chromium, nickel, molybdenum and nitrogen, resulting in an iron content close to or less than $50 \mathrm{wt} \%$. One of the most well known superaustenitic stainless steels is the UNS $\mathrm{S} 32654$ (also known as $654 \mathrm{SMO}^{\circledR}$ ): $\mathrm{Fe}-0.02 \mathrm{C}-3 \mathrm{Mn}-24 \mathrm{Cr}-$ $7.3 \mathrm{Mo}-22 \mathrm{Ni}-0.5 \mathrm{Cu}-0.5 \mathrm{~N}$ (wt $\%)$. In most of the steels shown in Table 1 the maximum silicon content is $1 \mathrm{wt} \%$. However, higher Si contents between 1 and $3 \mathrm{wt} \%$ can improve oxidation or scaling resistance. Even higher Si contents up to $5 \mathrm{wt} \%$ are used in certain cases to improve the corrosion resistance in nitric acid. Other alloying elements such as copper, boron or sulfur are sometimes added to the austenitic stainless steels and will be mentioned during the course of this review. 
Table 1. Compositions (in weight \%) of standard austenitic stainless steels (after Ref. 2)).

\begin{tabular}{|c|c|c|c|c|c|c|c|c|c|}
\hline \multirow[b]{2}{*}{ Type } & \multirow[b]{2}{*}{ UNS No. } & \multicolumn{8}{|c|}{ Composition, $\%(a)$} \\
\hline & & $\mathbf{C}$ & $\overline{M n}$ & Si & $\mathbf{C r}$ & $\mathbf{N i}$ & $\mathbf{P}$ & $\mathbf{s}$ & Other \\
\hline 201 & S20100 & 0.15 & $5.5-7.5$ & 1.00 & $16.0-18.0$ & $3.5-5.5$ & 0.06 & 0.03 & $0.25 \mathrm{~N}$ \\
\hline 202 & S20200 & 0.15 & $7.5-10.0$ & 1.00 & $17.0-19.0$ & $4.0-6.0$ & 0.06 & 0.03 & $0.25 \mathrm{~N}$ \\
\hline 205 & S20500 & $0.12-0.25$ & $14.0-15.5$ & 1.00 & $16.5-18.0$ & $1.0-1.75$ & 0.06 & 0.03 & $0.32-0.40 \mathrm{~N}$ \\
\hline 301 & S30100 & 0.15 & 2.0 & 1.00 & $16.0-18.0$ & $6.0-8.0$ & 0.045 & 0.03 & $\ldots$ \\
\hline 302 & S30200 & 0.15 & 2.0 & 1.00 & $17.0-19.0$ & $8.0-10.0$ & 0.045 & 0.03 & $\ldots$ \\
\hline 302B & S30215 & 0.15 & 2.0 & $2.0-3.0$ & $17.0-19.0$ & $8.0-10.0$ & 0.045 & 0.03 & $\ldots$ \\
\hline 303 & S30300 & 0.15 & 2.0 & 1.00 & $17.0-19.0$ & $8.0-10.0$ & 0.20 & $0.15 \mathrm{~min}$ & $0.6 \mathrm{Mo}(\mathrm{b})$ \\
\hline $303 \mathrm{Se}$ & S30323 & 0.15 & 2.0 & 1.00 & $17.0-19.0$ & $8.0-10.0$ & 0.20 & 0.06 & $0.15 \mathrm{~min} \mathrm{Se}$ \\
\hline 304 & S30400 & 0.08 & 2.0 & 1.00 & $18.0-10.0$ & $8.0-10.5$ & 0.045 & 0.03 & $\ldots$ \\
\hline $304 \mathrm{H}$ & S30409 & $0.04-0.10$ & 2.0 & 1.00 & $18.0-20.0$ & $8.0-10.5$ & 0.045 & 0.03 & $\ldots$ \\
\hline $304 \mathrm{~L}$ & S30403 & 0.03 & 2.0 & 1.00 & $18.0-20.0$ & $8.0-12.0$ & 0.045 & 0.03 & \\
\hline $304 \mathrm{LN}$ & S30453 & 0.03 & 2.0 & 1.00 & $18.0-20.0$ & $8.0-12.0$ & 0.045 & 0.03 & $0.10-0.16 \mathrm{~N}$ \\
\hline $302 \mathrm{Cu}$ & S30430 & 0.08 & 2.0 & 1.00 & $17.0-19.0$ & $8.0-10.0$ & 0.045 & 0.03 & $3.0-4.0 \mathrm{Cu}$ \\
\hline $304 \mathrm{~N}$ & S30451 & 0.08 & 2.0 & 1.00 & $18.0-20.0$ & $8.0-10.5$ & 0.045 & 0.03 & $0.10-0.16 \mathrm{~N}$ \\
\hline 305 & S30500 & 0.12 & 2.0 & 1.00 & $17.0-19.0$ & $10.5-13.0$ & 0.045 & 0.03 & $\ldots$ \\
\hline 308 & S30800 & 0.08 & 2.0 & 1.00 & $19.0-21.0$ & $10.0-12.0$ & 0.045 & 0.03 & $\ldots$ \\
\hline 309 & \$30900 & 0.20 & 2.0 & 1.00 & $22.0-24.0$ & $12.0-15.0$ & 0.045 & 0.03 & $\ldots$ \\
\hline $309 \mathrm{~S}$ & S30908 & 0.08 & 2.0 & 1.00 & $22.0-24.0$ & $12.0-15.0$ & 0.045 & 0.03 & $\ldots$ \\
\hline 310 & \$31000 & 0.25 & 2.0 & 1.50 & $24.0-26.0$ & $19.0-22.0$ & 0.045 & 0.03 & $\ldots$ \\
\hline $310 \mathrm{~S}$ & S31008 & 0.08 & 2.0 & 1.50 & $24.0-26.0$ & $19.0-22.0$ & 0.045 & 0.03 & $\ldots$ \\
\hline 314 & S31400 & 0.25 & 2.0 & $1.5-3.0$ & $23.0-26.0$ & $19.0-22.0$ & 0.045 & 0.03 & $\ldots$ \\
\hline 316 & S31600 & 0.08 & 2.0 & 1.00 & $16.0-18.0$ & $10.0-14.0$ & 0.045 & 0.03 & $2.0-3.0 \mathrm{Mo}$ \\
\hline $316 \mathrm{~F}$ & S31620 & 0.08 & 2.0 & 1.00 & $16.0-18.0$ & $10.0-14.0$ & 0.20 & $0.10 \mathrm{~min}$ & $1.75-2.5 \mathrm{Mo}$ \\
\hline $316 \mathrm{H}$ & S31609 & $0.04-0.10$ & 2.0 & 1.00 & $16.0-18.0$ & $10.0-14.0$ & 0.045 & 0.03 & $2.0-3.0 \mathrm{Mo}$ \\
\hline $316 \mathrm{~L}$ & S31603 & 0.03 & 2.0 & 1.00 & $16.0-18.0$ & $10.0-14.0$ & 0.045 & 0.03 & $2.0-3.0 \mathrm{Mo}$ \\
\hline $316 \mathrm{LN}$ & S31653 & 0.03 & 2.0 & 1.00 & $16.0-18.0$ & $10.0-14.0$ & 0.045 & 0.03 & $2.0-3.0 \mathrm{Mo} ; 0.10-0.16 \mathrm{~N}$ \\
\hline $310 \mathrm{~N}$ & S31651 & 0.08 & 2.0 & 1.00 & $16.0-18.0$ & $10.0-14.0$ & 0.045 & 0.03 & $2.0-3.0 \mathrm{Mo} ; 0.10-0.16 \mathrm{~N}$ \\
\hline 317 & $\$ 31700$ & 0.08 & 2.0 & 1.00 & $18.0-20.0$ & $11.0-15.0$ & 0.045 & 0.03 & $3.0-4.0 \mathrm{Mo}$ \\
\hline $317 \mathrm{~L}$ & \$31703 & 0.03 & 2.0 & 1.00 & $18.0-20.0$ & $11.0-15.0$ & 0.045 & 0.03 & 3.0-4.0 Mo \\
\hline 321 & S32100 & 0.08 & 2.0 & 1.00 & $17.0-19.0$ & $9.0-12.0$ & 0.045 & 0.03 & $5 \times \% \mathrm{C} \min \mathrm{Ti}$ \\
\hline $321 \mathrm{H}$ & S32109 & $0.04-0.10$ & 2.0 & 1.00 & $17.0-19.0$ & $9.0-12.0$ & 0.045 & 0.03 & $5 \times \% C \min \mathrm{Ti}$ \\
\hline 330 & N08330 & 0.08 & 2.0 & $0.75-1.5$ & $17.0-20.0$ & $34.0-37.0$ & 0.04 & 0.03 & \\
\hline 347 & S34700 & 0.08 & 2.0 & 1.00 & $17.0-19.0$ & $9.0-13.0$ & 0.045 & 0.03 & $10 \times \% C \min N b$ \\
\hline $347 \mathrm{H}$ & S34709 & $0.04-0.10$ & 2.0 & 1.00 & $17.0-19.0$ & $9.0-13.0$ & 0.045 & 0.03 & $8 \times \% C \min -1.0 \max N b$ \\
\hline 348 & S34800 & 0.08 & 2.0 & 1.00 & $17.0-19.0$ & $9.0-13.0$ & 0.045 & 0.03 & $\begin{array}{l}0.2 \mathrm{Co} ; 10 \times \% \mathrm{Cmin} \mathrm{Nb} ; \\
0.10 \mathrm{Ta}\end{array}$ \\
\hline $348 \mathrm{H}$ & S34809 & $0.04-0.10$ & 2.0 & 1.00 & $17.0-19.0$ & $9.0-13.0$ & 0.045 & 0.03 & $\begin{array}{r}0.2 \mathrm{Co} ; 10 \times \% \mathrm{Cmin}- \\
1.0 \mathrm{max} \mathrm{Nb} ; 0.10 \mathrm{Ta}\end{array}$ \\
\hline 384 & S38400 & 0.08 & 2.0 & 1.00 & $15.0-17.0$ & $17.0-19.0$ & 0.045 & 0.03 & $\ldots$ \\
\hline
\end{tabular}

\section{Phase Diagrams}

Phase diagrams are important to predict the phases present in the austenitic stainless steels. Nevertheless they have limitations due to the complexity of multicomponent thermodynamic calculations and also due to the transformation kinetics that may prevent the attainment of the equilibrium phases. Regarding the first limitation, the number of relevant components is often more than five and published diagrams are rarely found to contain more than four components. As to the second limitation, the diffusion of alloying elements in austenite can be very slow and the precipitation of certain intermetallic compounds can take thousands of hours.

\subsection{Equilibrium Diagrams}

In this section the most relevant features of the binary diagrams $^{3,4)} \mathrm{Fe}-\mathrm{Cr}$, Fe-Ni, Cr-Ni, Fe-Mo, Fe-Ti, Ni-Ti, Fe$\mathrm{Nb}, \mathrm{Fe}-\mathrm{Mn}$ and $\mathrm{Fe}-\mathrm{Si}$ are considered. Next the $\mathrm{Fe}-\mathrm{Cr}-\mathrm{Ni}$ and $\mathrm{Fe}-\mathrm{Cr}-\mathrm{Mo}$ ternary diagrams and the quaternary $\mathrm{Fe}-$ $\mathrm{Cr}-\mathrm{Ni}-\mathrm{Mo}$ diagram are discussed. The individual characteristics of each phase will be presented later in this review.

The two main features of the $\mathrm{Fe}-\mathrm{Cr}$ diagram, shown in Fig. 1, which are relevant to austenitic stainless steels, are the ferrite stabilizing character of $\mathrm{Cr}$ and the presence of sigma $(\sigma)$ phase.

The Fe-Ni diagram clearly shows the strong austenite stabilizing effect of $\mathrm{Ni}$. The intermetallic compound $\mathrm{Ni}_{3} \mathrm{Fe}$ is not normally observed in austenitic stainless steels. Also the $\mathrm{CrNi}_{2}$ compound present in the $\mathrm{Cr}-\mathrm{Ni}$ diagram does not form in austenitic stainless steels. The $\mathrm{Fe}-\mathrm{Mo}$ diagram shows that Mo is a strong ferrite stabilizer and also that it forms four intermetallic compounds with iron. Of those the sigma $(\sigma)$ phase and the Laves $\mathrm{Fe}_{2} \mathrm{Mo}$ phase often occur in the austenitic stainless steels. The mu $(\mu)$ phase, $\mathrm{Fe}_{7} \mathrm{Mo}_{6}$,

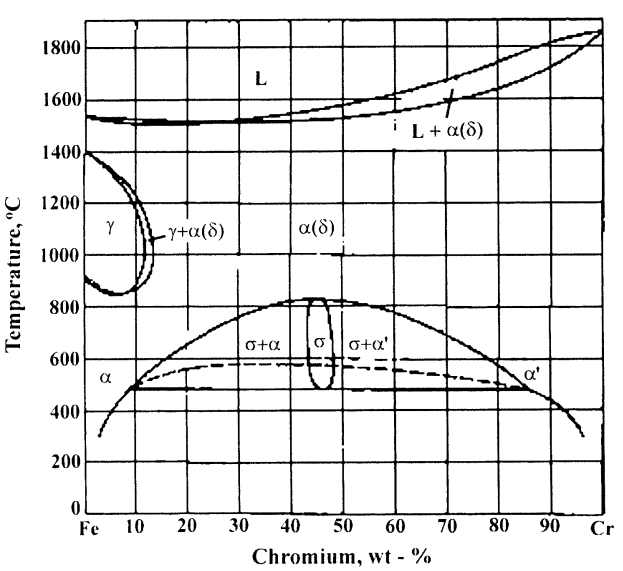

Fig. 1. Binary iron-chromium equilibrium diagram (after Ref. 3)).

occurs much less frequently in stainless steels. In the Fe-Ti diagram one can also see the very strong ferrite stabilizer character of the $\mathrm{Ti}$ and also the presence of a Laves, $\mathrm{Fe}_{2} \mathrm{Ti}$, phase that can occur in austenitic stainless steels, particularly in those in which the relationship $\mathrm{Ti}$ : $\mathrm{C}$ is high, "overstabilized steels". The Ni-Ti diagram shows the presence of the $\mathrm{Ni}_{3} \mathrm{Ti}$ that can be used to produce precipitation strengthening in higher $\mathrm{Ni}$ austenitic stainless steels.

The $\mathrm{Fe}-\mathrm{Nb}$ diagram shows the ferrite stabilizing character of the $\mathrm{Nb}$ and also the presence of a Laves phase, $\mathrm{Fe}_{2} \mathrm{Nb}$. The $\mathrm{Fe}_{2} \mathrm{Nb}$, similarly to the $\mathrm{Fe}_{2} \mathrm{Ti}$, can occur in austenitic stainless steels in which the relationship $\mathrm{Nb}: \mathrm{C}$ is high, "over-stabilized steels".

As to the Fe-Mn diagram the most relevant characteristic is the austenite stabilizing character of $\mathrm{Mn}$.

Finally the Fe-Si diagram shows a strong ferrite stabiliz- 
ing effect of $\mathrm{Si}$ but none of the five intermetallic compounds is found in commercial austenitic stainless steels.

The ternary $\mathrm{Fe}-\mathrm{Cr}-\mathrm{Ni}$ diagram is the basic diagram for austenitic stainless steels (Fig. 2). It shows the presence of only three solid phases: austenite, ferrite and sigma phase. For a high $\mathrm{Cr} / \mathrm{Ni}$ ratio delta ferrite may occur during solidification and sigma phase may occur during aging at temperatures between 550 and $900^{\circ} \mathrm{C}$. The compositional range of the sigma phase increases as the temperature is below $900^{\circ} \mathrm{C}$ as shown in Fig. 2.

The Fe-Cr-Mo diagram (Fig. 3) shows the presence of the chi $(\chi)$ phase. This phase is not found in the binary diagrams mentioned above and is frequently found during the aging of austenitic stainless steels containing Mo. Figure 4 shows two isothermal sections of the $70 \mathrm{wt} \% \mathrm{Fe}-\mathrm{Cr}-\mathrm{Ni}-\mathrm{Mo}$ quaternary system. One can see three intermetallic compounds that often form in austenitic stainless steels containing a few percent of Mo: sigma $(\sigma)$, chi $(\chi)$ and Laves phase $(\eta), \mathrm{Fe}_{2} \mathrm{Mo}$.

The non-metallic elements: carbon, nitrogen, boron and sulfur are usually present in relatively small quantities but nevertheless their effect can be extremely important. This will be discussed below in relation to the solubility and stability of the precipitates that contain these elements.

\subsection{Schaeffler, Delong and Other Nonequilibrium Diagrams}

However useful equilibrium phase diagrams might be, they are rarely sufficient to predict the resulting microstructure after solidification. As a result "practical" methods were developed. The best known of those is the Schaeffler diagram. Schaeffler ${ }^{9-11)}$ divided the alloying elements in two groups: ferrite and austenite stabilizers. Schaeffler developed a formula by means of which the elements of each group could be expressed as an equivalent chromium content and as an equivalent nickel content. An example of such a diagram can be found in Fig. 5. The regions of the diagram represent the microstructure of each class of stainless steels. Schaffler's method therefore allows a rough evaluation of the microstructure as a function of the steel composition. However it does not take into consideration the influence of the cooling rate and aging heat treatments. These diagrams have also been used to estimate the microstructure of weld metal. The empirical formulas and the experiments present a considerable scatter with regard to the determination of the amount of delta ferrite in austenitic weld metals. In this particular circumstance DeLong ${ }^{13)}$ suggested a comparative method that has been adopted as a standard procedure by the International Welding Institute.

Other researchers adopted a similar methodology such as Hull $^{14)}$ that analyzed 1400 specimens in order to determine the effect of 13 alloying elements $(\mathrm{Al}, \mathrm{C}, \mathrm{Cu}, \mathrm{Co}, \mathrm{Cu}, \mathrm{Mn}$, $\mathrm{Mo}, \mathrm{N}, \mathrm{Nb}, \mathrm{Si}, \mathrm{Ti}, \mathrm{Ta}, \mathrm{V}$ and $\mathrm{W}$ ) in addition to chromium and nickel in order to predict the resulting amount of delta ferrite in stainless steels. Espy ${ }^{15}$ ) proposed an extended Schaeffler diagram based on his study of the effects of $\mathrm{Cu}$, $\mathrm{N}, \mathrm{V}$ and Al. Both Hull and Espy obtained expressions for the equivalent chromium and nickel in broad agreement with those of Schaeffler. An interesting historical discussion, especially about the diagrams that preceded the Schaeffler work, can be found in reference. ${ }^{16)}$

These diagrams although lacking the sound thermodynamical basis of the equilibrium diagrams are nevertheless technological charts of practical importance.

Austenitic stainless steels can solidify by several mechanisms or modes. The prediction of their solidification mode

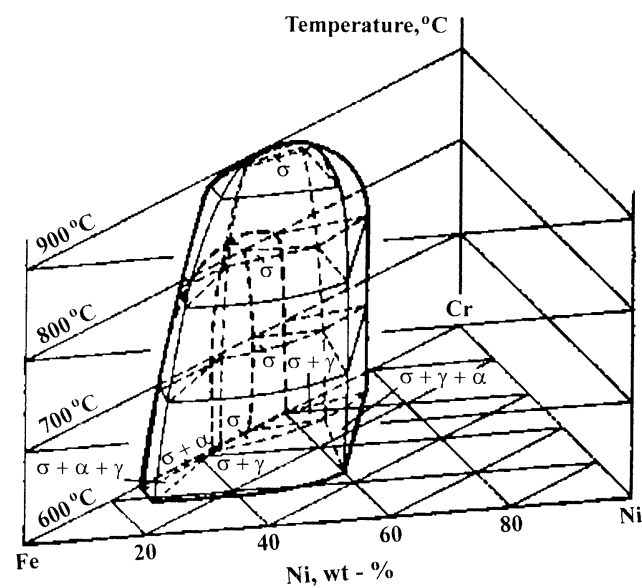

Fig. 2. Three-dimensional view of the $\mathrm{Fe}-\mathrm{Cr}-\mathrm{Ni}$ equilibrium diagram (after Ref. 5)).

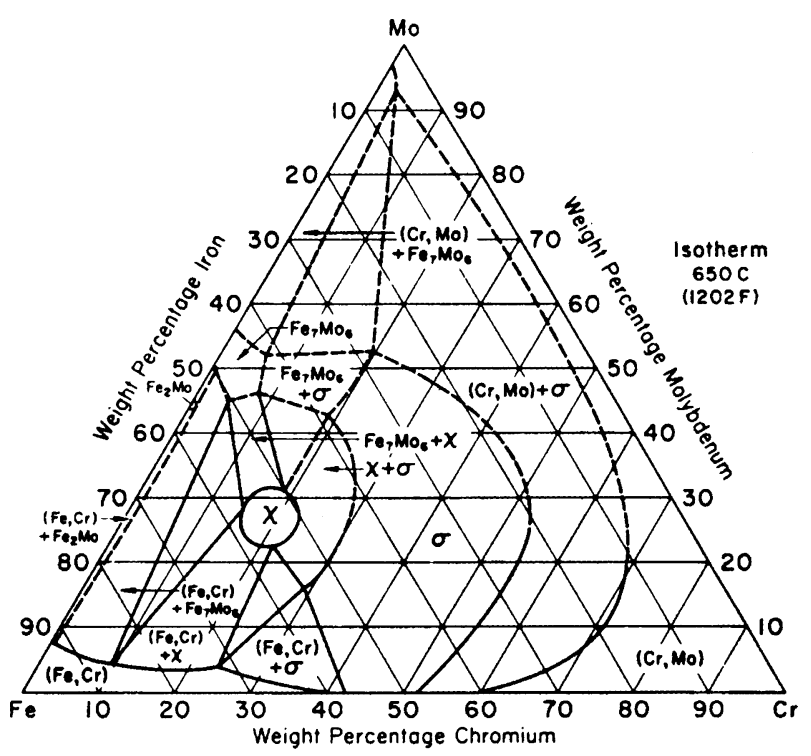

Fig. 3. $650^{\circ} \mathrm{C}$ isotherm of $\mathrm{Fe}-\mathrm{Cr}-\mathrm{Mo}$ equilibrium diagram (after Ref. 6)). $(\mathrm{Fe}, \mathrm{Cr})=$ solid solution, $(\mathrm{Cr}, \mathrm{Mo})=$ solid solution, $\mathrm{Fe}_{7} \mathrm{Mo}_{6}=\mathrm{mu}(\mu)$ phase, $\sigma=$ sigma phase, $\chi=$ chi phase.

and sequence can also be successfully done by using chromium and nickel equivalents ratios. ${ }^{17)}$

\section{Carbide Precipitation}

Wrought austenitic stainless steels usually contain up to $0.25 \mathrm{wt} \%$ of carbon (see Table 1) whereas some cast alloys may contain up to $0.75 \mathrm{wt} \%$. Carbon solubility in austenite decreases rapidly as the temperature decreases. In addition, a high $\mathrm{Ni}$ content also decreases the carbon solubility (see Fig. 6). As a consequence precipitation of $\mathrm{M}_{23} \mathrm{C}_{6}$ carbide, where $\mathrm{M}$ represents $\mathrm{Cr}, \mathrm{Fe}$, Mo and $\mathrm{Ni}$, is very common in this class of steels. The addition of "stabilizing elements" such as $\mathrm{Ti}, \mathrm{Nb}$ and $\mathrm{V}$ decreases the carbon solubility even further invariably resulting in MC type carbides, where $\mathrm{M}$ represents $\mathrm{Ti}, \mathrm{Nb}$ and/or $\mathrm{V}$. The presence of molybdenum in certain alloys can cause the precipitation of $\eta$, a $\mathrm{M}_{6} \mathrm{C}$ carbide, where $\mathrm{M}$ represents $\mathrm{Fe}, \mathrm{Mo}$ and $\mathrm{Cr}$. For usual carbon contents of wrought austenitic stainless steels precipitation of $\mathrm{M}_{7} \mathrm{C}_{3}$ carbide, where $\mathrm{M}$ represents $\mathrm{Cr}$ and $\mathrm{Fe}$, does not take place, but for high carbon contents such as those re- 

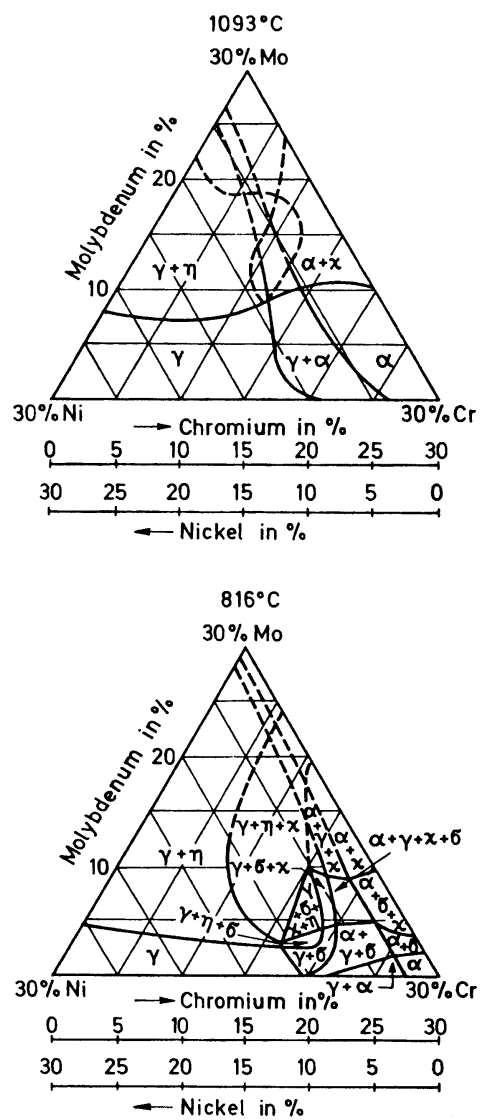

Fig. 4. Isothermal sections of the $\mathrm{Fe}-\mathrm{Cr}-\mathrm{Ni}-\mathrm{Mo}$ system with constant iron content of $70 \mathrm{wt} \%$ at 1093 and $816^{\circ} \mathrm{C}$ (after Refs. 7 and 8)). $\alpha=$ ferrite, $\gamma=$ austenite, $\sigma=$ sigma phase, $\chi=$ chi phase, $\eta=$ eta phase (Laves phase $\mathrm{Fe}_{2} \mathrm{Mo}$ ).

sulting from surface carburizing or in some high carbon cast alloys, $\mathrm{M}_{7} \mathrm{C}_{3}$ primary carbide can form from the melt. The carbide of the type $\mathrm{M}_{3} \mathrm{C}(\mathrm{M}=\mathrm{Fe}, \mathrm{Mn}, \mathrm{Cr})$ is not found in austenitic stainless steels.

In what follows precipitation of those four carbides in austenitic stainless steels is discussed in detail.

\section{1. $\mathrm{M}_{23} \mathrm{C}_{6}$}

$\mathrm{M}_{23} \mathrm{C}_{6}$ carbide was thought to be $\mathrm{Cr}_{4} \mathrm{C}$ until 1933 when Westgren $^{20)}$ showed that $\mathrm{Cr}_{23} \mathrm{C}_{6}$ was the correct composition. It has an fcc structure (more details in Table 2) and $\mathrm{Fe}$, Mo and Ni can substitute for $\mathrm{Cr}$ while $\mathrm{B}$ and $\mathrm{N}$ can partially substitute for $\mathrm{C}$. Its lattice parameter is three times that of the austenite that produces a characteristic diffraction pattern when examined in the transmission electron microscope. ${ }^{21)}$ The lattice parameter increases with Mo and decreases with $\mathrm{Fe}$ content. The Ni content of the carbide is normally less than $5 \mathrm{wt} \%$ and its effect on the lattice parameter has not been reported. The thermal history appears to have a strong influence on the $\mathrm{M}_{23} \mathrm{C}_{6}$ composition. According to Goldschmidt $\left.{ }^{22}\right) \mathrm{Cr}_{23} \mathrm{C}_{6}$ theoretically can dissolve up to $35 \mathrm{at} \%$ of the metallic elements. Philibert and coworkers $^{23)}$ have found up to $45 \mathrm{wt} \%$ of $\mathrm{Fe}$ in the carbide in a $\mathrm{Fe}-18 \mathrm{wt} \% \mathrm{Cr}-8 \mathrm{wt} \% \mathrm{Ni}$ steel after a short heat treatment at $750^{\circ} \mathrm{C}$. After holding for $24 \mathrm{~h}$ at this same temperature the $\mathrm{Fe}$ content decreased to $24 \mathrm{wt} \%$. Similar behavior was found by Da Casa and coworkers. ${ }^{24)}$ In steels containing Mo, such as AISI 316 and $316 \mathrm{~L}$, the increase in lattice parameter with aging time can be explained by an increase in the Mo content of the carbide. ${ }^{25)}$ The atoms of Mo and W

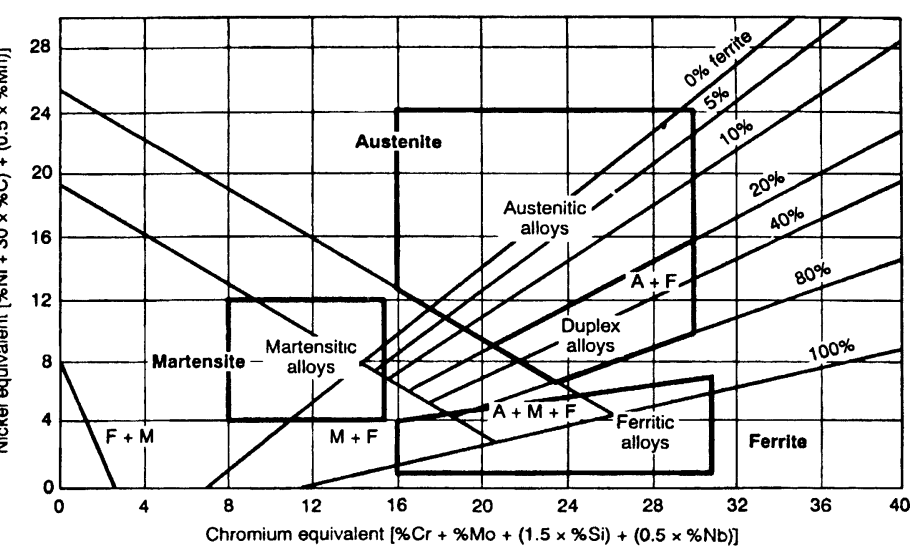

Fig. 5. Schaeffler constitution diagram for stainless steels (after Refs. 2) and 12)). The compositional ranges of the ferritic, martensitic, austenitic, and duplex alloys have been superimposed on this diagram.

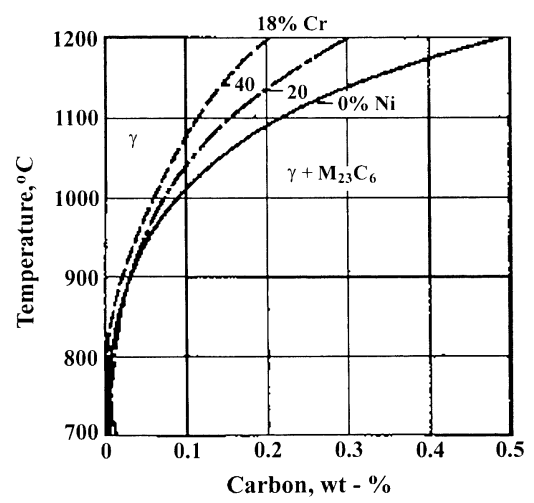

Fig. 6. Influence of temperature and nickel content on the carbon solubility in $\mathrm{Fe}-18 \mathrm{wt} \% \mathrm{Cr}$ austenite (after Refs. 8), 18), 19)).

can occupy only certain positions in the carbide structure, ${ }^{22)}$ the maximum fraction of which is $8.7 \mathrm{at} \%$. The following chemical composition was found ${ }^{25)}$ for the $\mathrm{M}_{23} \mathrm{C}_{6}$ in a AISI 316 steel: $63 \mathrm{wt} \% \mathrm{Cr} ; 18 \mathrm{wt} \% \mathrm{Fe} ; 14 \mathrm{wt} \%$ Mo and $5 \mathrm{wt} \%$ $\mathrm{Ni}$, that corresponds approximately to $\left(\mathrm{Cr}_{16} \mathrm{Fe}_{5} \mathrm{Mo}_{2}\right) \mathrm{C}_{6}$. In that work $^{25)}$ the lattice parameter was found to vary between 1.0569 and $1.0676 \mathrm{~nm}$. The presence of nitrogen in austenitic stainless steels inhibits the precipitation of $\mathrm{M}_{23} \mathrm{C}_{6}{ }^{26)}$

The carbon solubility in equilibrium with the $\mathrm{M}_{23} \mathrm{C}_{6}$ carbide in a AISI 316 austenitic stainless steel was determined experimentally ${ }^{27)}$ and is given below:

$$
\log _{10}[\mathrm{C}(\mathrm{ppm})]=7.771-(6272 / T) \text {. }
$$

This relation yields values for the solubility of carbon of $0.16 \mathrm{wt} \%$ and $4 \mathrm{ppm}$ at 1100 and $600^{\circ} \mathrm{C}$, respectively. Therefore in non-stabilized austenitic stainless steels there is substantial precipitation during aging or during service at a high temperature.

The most favorable sites for the $\mathrm{M}_{23} \mathrm{C}_{6}$ carbide precipitation are grain boundaries, followed by incoherent twin boundaries, coherent twin boundaries and finally at the dislocations within the grains. ${ }^{25)}$ Within the grains the precipitates exhibit the following orientation relationship with the austenitic matrix ${ }^{25,28)}$.

$$
\begin{gathered}
\{001\}_{\gamma} / /\{001\}_{\mathrm{M}_{23} \mathrm{C}_{6}} \\
\langle 100\rangle_{\gamma} / /\langle 100\rangle_{\mathrm{M}_{23} \mathrm{C}_{6}}
\end{gathered}
$$

Figure 7 illustrates the precipitation of $\mathrm{M}_{23} \mathrm{C}_{6}$ on a grain 
Table 2. Crystal structures and compositions of carbides which may appear in austenitic stainless steels.

\begin{tabular}{|c|c|c|c|c|c|c|}
\hline Carbide & Unit cell & $\begin{array}{c}\text { Atoms } \\
\text { per cell }\end{array}$ & $\begin{array}{c}\text { Space } \\
\text { group }\end{array}$ & $\begin{array}{c}\text { Lattice parameters } \\
(\mathrm{nm})\end{array}$ & $\begin{array}{c}\text { Principal } \\
\text { metallic } \\
\text { elements }\end{array}$ & Occurrence \\
\hline $\mathrm{M}_{23} \mathrm{C}_{6}$ & $\mathrm{fcc}$ & 116 & $\mathrm{Fm} 3 \mathrm{~m}$ & $\mathrm{a}=1.057-1.068$ & $\begin{array}{c}\mathrm{Cr}, \mathrm{Fe}, \\
\mathrm{Mo}, \mathrm{Ni}\end{array}$ & Nearly all stainless steels \\
\hline $\mathrm{MC}$ & ord fcc & 8 & $\mathrm{Fm} 3 \mathrm{~m}$ & $\mathrm{a}=0.4131-0.4698$ & $\begin{array}{c}\mathrm{Ti}, \mathrm{Nb}, \mathrm{V} \\
\text { and/or } \mathrm{Zr}\end{array}$ & AISI 321, AISI 347 \\
\hline $\mathrm{M}_{6} \mathrm{C}$ & $\mathrm{fcc}$ & 112 & $\mathrm{Fd} 3 \mathrm{~m}$ & $\mathrm{a}=1.085-1.128$ & $\mathrm{Fe}, \mathrm{Mo}, \mathrm{Cr}$ & $\mathrm{AISI} 316, \mathrm{AISI} 316 \mathrm{~L}$ \\
\hline $\mathrm{M}_{7} \mathrm{C}_{3}$ & $\begin{array}{c}\text { pseudo } \\
\text { hex. }\end{array}$ & 40 & $\mathrm{Pnma}$ & $\begin{array}{l}\mathrm{a}=0.6928-0.6963 \\
\mathrm{c}=0.4541-0.4511\end{array}$ & $\mathrm{Cr}, \mathrm{Fe}$ & $\mathrm{HH} 40, \mathrm{HK} 40, \mathrm{HP} 40$ \\
\hline
\end{tabular}

boundary of an titanium stabilized austenitic stainless steel after $1000 \mathrm{~h}$ at $600^{\circ} \mathrm{C} .^{29)}$

Those grain boundary nucleated carbides have a definite orientation relationship with only one austenitic grain and grow preferentially into the grain with which they do not have a definite orientation relationship. ${ }^{29,30)}$ The tendency of $\mathrm{M}_{23} \mathrm{C}_{6}$ to precipitate intergranularly depends strongly on the grain boundary structure. ${ }^{31)}$ Carbides tend to be detected at grain boundaries with higher $\Sigma$ values or larger angles $(\Delta \theta)$ from low- $\Sigma$ coincidence site lattice misorientations. ${ }^{31)}$

High solution annealing temperatures can accelerate the start of the precipitation. ${ }^{25)}$ Cold deformation, after solution annealing and before aging also accelerates precipitation and favors precipitation sites within the grains. ${ }^{25)}$

The $\mathrm{M}_{23} \mathrm{C}_{6}$ carbide is normally the first phase to form in austenitic stainless steels. Depending on the carbon content, a significant amount of carbides can form after only a few minutes between 650 and $750^{\circ} \mathrm{C}$. It is interesting however that in both stabilized and non-stabilized austenitic stainless steels there is at least a partial dissolution of $\mathrm{M}_{33} \mathrm{C}_{6}$ for long aging times. For example, Grot and Spruiell ${ }^{32}$ ) found the presence of $\mathrm{M}_{23} \mathrm{C}_{6}$ between 550 and $900^{\circ} \mathrm{C}$ for aging times up to $4000 \mathrm{~h}$ in an AISI $321 \mathrm{Ti}$ stabilized steel. In this same steel Leitnaker and Bentley ${ }^{33)}$ could not find $\mathrm{M}_{23} \mathrm{C}_{6}$ after 17 years at $600^{\circ} \mathrm{C}$. In the case of the stabilized steels the $\mathrm{M}_{23} \mathrm{C}_{6}$ dissolution takes place due to the precipitation of the more stable MC carbides. In non-stabilized steels the dissolution of $\mathrm{M}_{23} \mathrm{C}_{6}$ can also occur if there is significant precipitation of intermetallic phases such as $\sigma$ phase, $\chi$ phase and Laves phase. The intermetallic phase precipitation can lower the $\mathrm{Cr}$ and Mo content of the matrix, increasing the carbon solubility leading to a partial dissolution of the $\mathrm{M}_{23} \mathrm{C}_{6}$ carbide. $^{25)}$

The $\mathrm{M}_{23} \mathrm{C}_{6}$ carbide is normally undesirable since its presence is associated with sensitization or intergranular corrosion and a decrease in ductility and toughness. On the other hand it has been shown that the presence of $\mathrm{M}_{23} \mathrm{C}_{6}$ carbides on the grain boundaries can make grain boundary sliding more difficult thus improving creep ductility. ${ }^{34)}$

\section{2. $\mathrm{MC}$}

The MC ( $\mathrm{M}=\mathrm{Ti}, \mathrm{Zr}, \mathrm{Hf}, \mathrm{V}, \mathrm{Nb}$ and $\mathrm{Ta})$ carbides are very stable and are invariably present in stabilized austenitic stainless steels such as AISI 321 (Ti stabilized), AISI 347 and 348 ( $\mathrm{Nb}$ stabilized). The addition of elements that form MC carbides, normally called stabilizing elements, aims at hindering $\mathrm{M}_{23} \mathrm{C}_{6}$ precipitation and its associated undesirable consequences, particularly susceptibility to intergranular corrosion. However the addition of Ti, $\mathrm{Zr}$ or Hf results, unavoidably, in the formation of MN nitrides (see Sec. 5.1) and $\mathrm{M}_{4} \mathrm{C}_{2} \mathrm{~S}_{2}$ carbosulfides (see Sec. 5.3) that are even more stable than the $\mathrm{MC}$ carbide. ${ }^{29,31,32)}$ Laves phase, $\mathrm{Fe}_{2} \mathrm{M}$ $(\mathrm{M}=\mathrm{Ti}, \mathrm{Zr}, \mathrm{Hf}, \mathrm{V}, \mathrm{Nb}$ and $\mathrm{Ta}$ ), can also form (see Sec. 4.1.3). The precipitation of those phases will be discussed in subsequent sections.

The MC carbides have an fcc, $\mathrm{NaCl}$ type, structure.

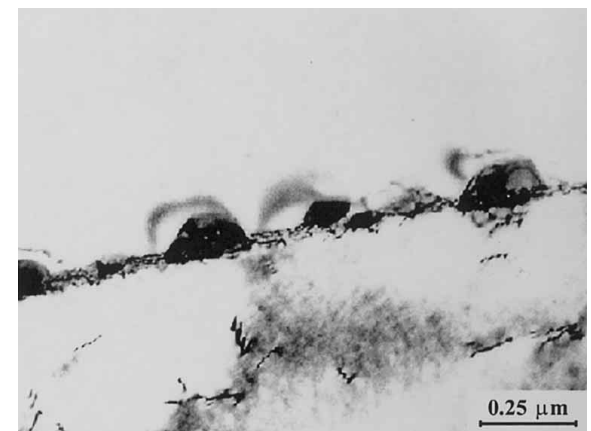

Fig. 7. Grain-boundary $\mathrm{M}_{23} \mathrm{C}_{6}$ morphology in an austenitic stainless steel obtained by transmission electron microscopy (after A. F. Padilha, USP, Brazil).

Nitrogen can partially substitute for carbon in these carbides causing a decrease in the lattice parameter. They are sometimes referred to as carbonitrides, $\mathrm{M}(\mathrm{C}, \mathrm{N})$. The dissolution of Mo in TiC has been reported. ${ }^{29)}$ However, there is little information available about the dissolution of metallic elements in MC carbides that form in the austenitic stainless steels. On the other hand specific studies on the phase diagrams of the carbides ${ }^{35,36)}$ report considerable miscibility among the $\mathrm{MC}$ carbides ( $\mathrm{TiC}, \mathrm{ZrC}, \mathrm{HfC}, \mathrm{VC}, \mathrm{NbC}$ and $\mathrm{TaC}$ ) and also that these carbides can dissolve some $\mathrm{Cr}$, Mo and $\mathrm{W}$. Andrén and coworkers ${ }^{37)}$ report that for short aging times, typically $3 \mathrm{~h}$ at $750^{\circ} \mathrm{C}$, the $\mathrm{MC}$ carbides are markedly sub-stoichiometric and can dissolve a considerable amount of Cr. Thorvaldsson and Dunlop ${ }^{38)}$ found that a substantial amount of $\mathrm{Cr}$ is present in the $\mathrm{MX}(\mathrm{X}=\mathrm{C}$ and/or $\mathrm{N})$ precipitates but this amount decreases with increased aging time. The carbon solubility is smaller in the stabilized steels than on the non stabilized steels. This is shown by Eq. (2) determined $^{39)}$ for a steel with composition $\mathrm{Fe}-18 \mathrm{wt} \% \mathrm{Cr}-$ $12 \mathrm{wt} \% \mathrm{Ni}-\mathrm{Nb}$ and Eq. (3) determined ${ }^{40)}$ for the titanium stabilized AISI 321 steel:

$$
\begin{aligned}
& \log _{10}[\mathrm{Nb}][\mathrm{C}]=4.55-(9350 / T) \\
& \log _{10}[\mathrm{Ti}][\mathrm{C}]=4.46-(8900 / T) . .
\end{aligned}
$$

[Nb], [Ti] and [C] in Eqs. (2) and (3) are matrix concentrations in weight percent.

The presence of MC in stabilized steels, even for very low carbon contents, is expected. They basically show ${ }^{29,32,33}$ ) two types of distribution: (i) a coarse dispersion, $1-10 \mu \mathrm{m}$ in size, of primary particles formed during solidification; and (ii) a fine dispersion, $5-500 \mathrm{~nm}$ in size, of secondary precipitates. In the stabilized steels, part of the primary carbides can be dissolved during the solution annealing heat treatment at temperatures ranging from 1050 to $1150^{\circ} \mathrm{C}$, and they reprecipitate as fine secondary precipitates during the aging heat treatment or when these materials are subjected to high-temperature applications. The MC carbide precipitation is predominantly intragranular, on dislocations and stacking faults. However, $\mathrm{MC}$ precipitation at grain boundaries can also occur. ${ }^{29)}$ Nucleation and growth of $\mathrm{NbC}$ particles at grain boundaries is favored at extrinsic grain boundary dislocations and at grain boundary topographical defects. $^{41,42)}$ Figure 8 illustrates the precipitation of (Ti, $\mathrm{Mo}) \mathrm{C}$ on dislocations in a titanium stabilized austenitic stainless steel after $24 \mathrm{~h}$ at $900^{\circ} \mathrm{C} .^{29)}$

Although the lattice parameter difference between the matrix and the $\mathrm{MC}$ carbides is higher than $10 \%$, for instance for $\mathrm{NbC}$ the mismatch is close to $25 \%$, a cube-on- 


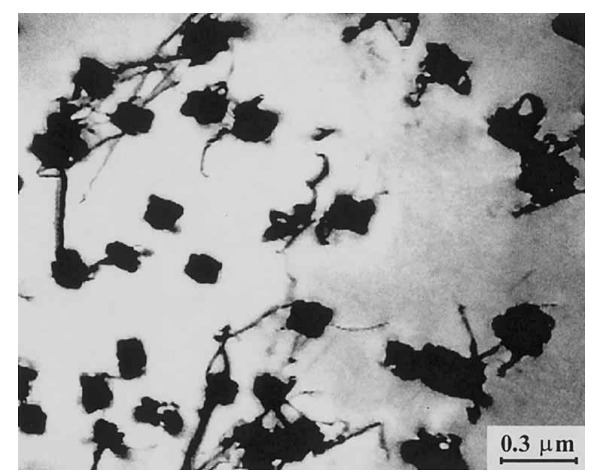

Fig. 8. MC carbides precipitation on dislocations in a titanium stabilized austenitic stainless steel observed by transmission electron microscopy (after A. F. Padilha, USP, Brazil).

cube orientation relationship is frequently found between the $\mathrm{MC}$ and parent austenite:

$$
\begin{aligned}
& \{001\}_{\gamma} / /\{001\}_{\mathrm{MC}} \\
& \langle 100\rangle_{\gamma} / /\langle 100\rangle_{\mathrm{MC}}
\end{aligned}
$$

It is worthy of note that the addition of stabilizing elements does not wholly suppress precipitation of $\mathrm{M}_{23} \mathrm{C}_{6}$, even if one adds a large amount of stabilizing elements. $\mathrm{M}_{23} \mathrm{C}_{6}$ carbides have been found ${ }^{43)}$ in stabilized steels in which the $\mathrm{Ti} / \mathrm{C}$ ratio was as high as 34 when the stoichiometric ratio is only 5. The precipitation of $\mathrm{M}_{23} \mathrm{C}_{6}$ becomes comparatively easier in relation to that of $\mathrm{MC}$ carbides as the temperature is decreased. For example around $600^{\circ} \mathrm{C}$, $\mathrm{M}_{23} \mathrm{C}_{6}$ precipitation occurs before the $\mathrm{MC}$ carbide precipitation. ${ }^{29)}$ This type of carbide has a particularly large resistance to coarsening. ${ }^{33,44)}$

Finally, it must be mentioned that there is experimental evidence ${ }^{38,45,46)}$ that the $\mathrm{MC}$ to $\mathrm{M}_{23} \mathrm{C}_{6}$ transformation can take place in certain austenitic alloys after long times. However, in order to clarify this more systematic studies are required on the effect of variables such as $\mathrm{MC}$ carbide type and $\mathrm{M} / \mathrm{C}$ ratio of the steel, $\mathrm{Cr} / \mathrm{Ni}$ ratio of the steel, temperature, applied creep stress and precipitation sites.

\section{3. $\mathbf{M}_{6} \mathrm{C}$}

The carbides of the type $\mathrm{M}_{6} \mathrm{C}(\mathrm{M}=\mathrm{Fe}, \mathrm{Cr}, \mathrm{Mo}, \mathrm{W}, \mathrm{Nb}$ and $\mathrm{V}$ ), also known as $\eta$-carbide, are often found in austenitic stainless steels containing molybdenum, tungsten and niobium, especially molybdenum. The $\mathrm{M}_{6} \mathrm{C}$ carbide invariably contains more than one metallic element, requiring the presence of at least three types of atoms and is usually represented by the formulae $\mathrm{A}_{3} \mathrm{~B}_{3} \mathrm{C}$ or $\mathrm{A}_{4} \mathrm{~B}_{2} \mathrm{C}$. The number of carbon atoms per unit cell is variable and there is evidence of this being a carbon sub-stoichiometric carbide. ${ }^{47}$ This type of carbide has an fcc, diamond type, structure. Nitrogen additions are believed ${ }^{48)}$ to favor $\mathrm{M}_{6} \mathrm{C}$ precipitation to the detriment of $\mathrm{M}_{23} \mathrm{C}_{6}$, because the former is able to dissolve more nitrogen than the latter. Nitrogen atoms replace carbon atoms in the lattice, reduce the lattice parameter and stabilize this phase. $\mathrm{As}_{23} \mathrm{C}_{6}$ absorbs molybdenum during aging and the molybdenum content in $\mathrm{M}_{23} \mathrm{C}_{6}$ exceeds a threshold, an in situ $\mathrm{M}_{23} \mathrm{C}_{6} \rightarrow \mathrm{M}_{6} \mathrm{C}$ transformation is possible, as originally suggested by Goldschmidt ${ }^{49)}$ and reinforced by Weiss and Stickler. ${ }^{25}$ ) Due to the size of their unit cells, $\mathrm{M}_{6} \mathrm{C}$ and austenite might be expected to show a cube-on-cube orientation relationship.

Comparatively less attention has been given to $\mathrm{M}_{6} \mathrm{C}$ carbide in the literature, because it is not found (or only found in small quantities) in most stainless steels. With the advent of the "superaustenitic" stainless steels that contain high levels of molybdenum and nitrogen, it is likely that more investigations will be done on this type of carbide and its effect on properties.

\section{4. $\mathrm{M}_{7} \mathrm{C}_{3}$}

$\mathrm{M}_{7} \mathrm{C}_{3}$ carbide has a pseudo-hexagonal crystal structure. Although it occurs both in the $\mathrm{Fe}-\mathrm{Cr}-\mathrm{C}$ and $\mathrm{Fe}-\mathrm{Cr}-\mathrm{Ni}-\mathrm{C}$ systems, ${ }^{50)}$ it does not occur in wrought stainless steels of the 300 series possessing the usual carbon content. The $\mathrm{M}_{7} \mathrm{C}_{3}(\mathrm{M}=\mathrm{Cr}, \mathrm{Fe})$ carbides can only be found in austenitic stainless steels for very high carbon:chromium ratios, ${ }^{17,51)}$ for example, during carburizing. During surface carburization of type AISI 316 stainless steel, ${ }^{52)}$ the near surface region of the steel comprised predominantly $\mathrm{M}_{7} \mathrm{C}_{3}$ where the local carbon content was about $4 \mathrm{wt} \%$. The ratio to $\mathrm{M}_{23} \mathrm{C}_{6}$ to $\mathrm{M}_{7} \mathrm{C}_{3}$ phases increased as the carbon content decreased from the surface to the center. Carburizing studies of AISI 300 series steels are not common and most of them were carried out in the 1970's. These studies were related to fast breeder reactors where the carburizing medium was liquid sodium. $\mathrm{M}_{7} \mathrm{C}_{3}$ is one of the most common phases in centrifugally cast austenitic stainless steels for gas-reformer and pyrolysis-furnace tubes used in the petrochemical industry $^{53,54)}$ (see Fig. 9). $\mathrm{M}_{7} \mathrm{C}_{3}$ carbides are also important in high-chromium white cast irons that are traditionally employed in applications where there is a need for high resistance to abrasive wear. One common heat resistant steel of this type is $\mathrm{HK} 40(\mathrm{Fe}-0.4 \mathrm{wt} \% \mathrm{C}-25 \mathrm{wt} \% \mathrm{Cr}-20 \mathrm{wt} \% \mathrm{Ni})$ specified in the ASTM A297 standard. During solidification, a eutectic of $\mathrm{M}_{7} \mathrm{C}_{3}$ and austenite is formed. ${ }^{53)}$ During creep or service ${ }^{53)}$ in the range $750-1000^{\circ} \mathrm{C}, \mathrm{M}_{7} \mathrm{C}_{3}$ gradually transforms to the more stable $\mathrm{M}_{23} \mathrm{C}_{6}$. The high chromium white cast irons contain 11-30 wt $\%$ chromium and 1.8-3.6 $\mathrm{wt} \%$ carbon, as well as additions of molybdenum, manganese, nickel, and copper. The as-cast microstructure of this type of white cast iron consists of a dispersion of eutectic $\mathrm{M}_{7} \mathrm{C}_{3}$ and eventually $\mathrm{M}_{3} \mathrm{C}$ in an austenitic matrix. ${ }^{55)}$ In this case, the as-cast microstructure can be significantly changed by austenite destabilization heat treatments, when precipitation of secondary carbides of types $\mathrm{M}_{3} \mathrm{C}$ or $\mathrm{M}_{7} \mathrm{C}_{3}$ or even $\mathrm{M}_{23} \mathrm{C}_{6}$ takes place. ${ }^{55,56)}$

\section{Precipitation of Intermetallic Phases}

The three intermetallic phases most frequently found in the austenitic stainless steels are sigma phase $(\sigma)$, chi phase $(\chi)$ and Laves phase $(\eta)$. Other intermetallic phases can also be occasionally found: $\mathrm{G}, \mathrm{R}, \mathrm{mu}(\mu)$, gamma prime $\left(\gamma^{\prime}\right)$, gamma double prime $\left(\gamma^{\prime \prime}\right), \eta-\mathrm{Ni}_{3} \mathrm{Ti}$ and $\delta-\mathrm{Ni}_{3} \mathrm{Nb}$. Precipitation of intermetallic phases from austenite is normally associated with undesirable consequences like matrix impoverishment in alloying elements such as chromium, molybdenum, and niobium as well as loss of ductility, toughness and corrosion resistance. Exceptions are $\gamma^{\prime}$ $\mathrm{Ni}_{3}(\mathrm{Al}, \mathrm{Ti})$ in precipitation-hardening iron-based superalloys and the Laves phase, $\mathrm{Fe}_{2} \mathrm{Nb}$, in austenitic stainless steels, since their occurrence can result in precipitation hardening.

Intermetallic phases that occur in austenitic stainless steels (see Table 3) can be classified in two groups: i) topologically close packed phases, like $\sigma, \chi$, Laves $(\eta), \mathrm{G}, \mathrm{R}$ and $\mathrm{Mu}(\mu)$ and ii) geometrically close packed phases, like $\gamma^{\prime}, \gamma^{\prime \prime}, \quad \eta-\mathrm{Ni}_{3} \mathrm{Ti}$ and $\delta-\mathrm{Ni}_{3} \mathrm{Nb}$. The topologically close packed phases (TCP phases) are characterized by close- 
packed layers of atoms separated from one another by relatively large interatomic distances. ${ }^{57)}$ The layers of closepacked atoms are displaced from one another by sandwiched large atoms, developing a characteristic topology. ${ }^{57}$ In contrast, the geometrically close packed phases (GCP phases), are close packed in all directions. GCP phases have been observed to form mainly in nickel base alloys whereas the TCP phases have been observed mainly in the iron base alloys. ${ }^{58)}$ In what follows, the precipitation of those phases in the austenitic stainless steels is discussed in detail.

\subsection{Topologically Close Packed Phases (TCP Phases)}

\subsubsection{Sigma Phase $(\sigma)$}

Sigma phase is probably the most studied and undesirable intermetallic phase of those mentioned above. Already in 1907, even before the discovery of the stainless steels, Treitschke and Tamman, ${ }^{59)}$ studying the $\mathrm{Fe}-\mathrm{Cr}$ system, conjectured that there was a compound in the $30-50 \mathrm{wt} \% \mathrm{Cr}$ range. In 1927, Bain and Griffiths ${ }^{60)}$ found in the $\mathrm{Fe}-\mathrm{Cr}-\mathrm{Ni}$ system a hard and brittle phase that they called " $\mathrm{B}$ constituent" where "B" stands for brittle. In 1936, Jett and Foote $^{61)}$ called it sigma phase and in 1951, Bergmann and Shoemaker ${ }^{62)}$ studied it in detail and obtained the crystallographic structure of the sigma phase in the Fe-Cr system.

Sigma-phase appears in several binary, tertiary, and quaternary systems such as $\mathrm{Fe}-\mathrm{Cr}, \mathrm{Fe}-\mathrm{Mo}, \mathrm{Fe}-\mathrm{V}, \mathrm{Fe}-\mathrm{Mn}$,

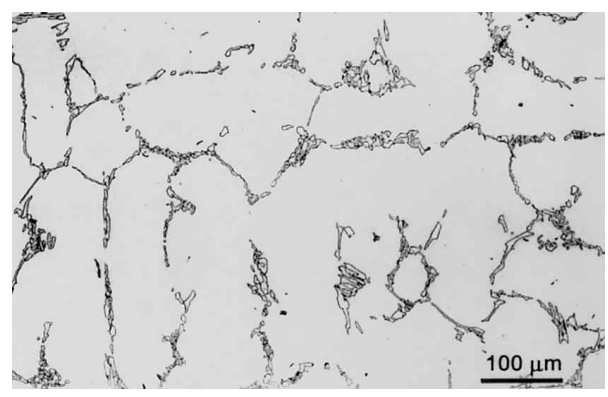

Fig. 9. As cast microstructure showing $\mathrm{M}_{7} \mathrm{C}_{3}$ carbide network in an $\mathrm{HP}(\mathrm{Fe}-0.43 \mathrm{wt} \% \mathrm{C}-26 \mathrm{wt} \% \mathrm{Cr}-32.6 \mathrm{wt} \% \mathrm{Ni})$ austenitic stainless steel obtained by light microscopy (courtesy of Luiz Henrique de Almeida, UFRJ, Brazil).
$\mathrm{Fe}-\mathrm{Cr}-\mathrm{Ni}, \mathrm{Fe}-\mathrm{Cr}-\mathrm{Mo}, \mathrm{Fe}-\mathrm{Cr}-\mathrm{Mn}$ and $\mathrm{Fe}-\mathrm{Cr}-\mathrm{Ni}-\mathrm{Mo}$. The $\sigma$-phase occurs for an electron/atom ratio between 5.6 and 7 and for an atomic radius ratio, in binary systems, between 0.96 and 1.16. Sigma phase precipitation in austenitic stainless steels occurs between 550 and $900^{\circ} \mathrm{C}$. A typical $\sigma$ phase chemical composition, found ${ }^{25)}$ in AISI 316 or $316 \mathrm{~L}$ austenitic stainless steels, is the following (in wt $\%$ ): $55 \%$ $\mathrm{Fe} ; 29 \% \mathrm{Cr} ; 11 \% \mathrm{Mo}$ and $5 \% \mathrm{Ni}$. The composition of sigma phase in austenitic stainless steels can be approximately written as: $(\mathrm{Fe}, \mathrm{Ni})_{3}(\mathrm{Cr}, \mathrm{Mo})_{2}$. Alloying elements such as chromium, manganese, molybdenum, tungsten, vanadium, silicon, titanium, niobium, and tantalum favor $\sigma$-phase formation, whereas nickel, cobalt, aluminum, carbon and nitrogen hinder its precipitation. A method has been developed by Dean and Plumbridge ${ }^{63)}$ to estimate the sigma-forming tendency of a certain austenitic stainless steel based on its chemical composition. It precipitates mainly on grain boundaries, especially on triple junctions, and on incoherent twin boundaries and intragranular inclusions. $^{25)}$ Its morphology is usually equiaxed. Figure 10 illustrates the precipitation of sigma phase on the grain boundaries of an AISI 316 steel after $28100 \mathrm{~h}$ at $700^{\circ} \mathrm{C}$. As described before, sigma phase precipitation depleted the adjacent matrix in chromium and molybdenum and thereby caused dissolution of carbides in this region.

Several orientation relationships between $\sigma$ phase and austenite have been reported. Lewis ${ }^{64)}$ and Weiss and Stickler $^{25)}$ found:

$$
\begin{aligned}
& (111)_{\gamma} / /(001)_{\sigma} \\
& {[0 \overline{1} 1]_{\gamma} / /[140]_{\sigma}}
\end{aligned}
$$

whereas Beckitt ${ }^{65)}$ found:

$$
\begin{aligned}
& (111)_{\gamma} / /(001)_{\sigma} \\
& {[\overline{1} 10]_{\gamma} / /[\overline{1} 10]_{\sigma}}
\end{aligned}
$$

and Duhaj et al. ${ }^{66)}$ found a mixture of several orientation relationships.

Sigma phase precipitation has a very slow kinetics and precipitate formation can take hundreds and sometimes thousands of hours. There are at least three reasons for the

\begin{tabular}{|c|c|c|c|c|c|c|}
\hline Phase & Unit cell & $\begin{array}{l}\text { Atoms } \\
\text { per cell }\end{array}$ & $\begin{array}{l}\text { Space } \\
\text { group }\end{array}$ & \begin{tabular}{|l|} 
Lattice \\
parameters \\
$(\mathrm{nm})$
\end{tabular} & Composition & Occurrence \\
\hline $\begin{array}{l}\text { Sigma } \\
(\sigma)\end{array}$ & bct & 30 & $\mathrm{P} 4_{2} / \mathrm{mnm}$ & $\begin{array}{l}a=0.87-0.92 \\
c=0.4554-0.48\end{array}$ & $(\mathrm{Fe}, \mathrm{Ni})_{x}(\mathrm{Cr}, \mathrm{Mo})_{y}$ & $\begin{array}{lrr}\text { AISI } 304 ; & \text { AISI } \\
304 L ; & \text { AISI } & 316 ; \\
\text { AISI } 316 L ; & \text { AISI } \\
321 ; & \text { AISI 347 } & \\
\end{array}$ \\
\hline $\begin{array}{l}\text { Chi } \\
(\chi)\end{array}$ & $\mathrm{bcc}$ & 58 & $143 m$ & $a=0.881-0.895$ & $(\mathrm{Fe}, \mathrm{Ni})_{36} \mathrm{Cr}_{12} \mathrm{Mo}_{10}$ & $\begin{array}{l}\text { AISI 316; AISI } \\
\text { 316L; AISI } 321\end{array}$ \\
\hline $\begin{array}{l}\text { Laves } \\
(\eta)\end{array}$ & hex. & 12 & $\mathrm{P}_{3} / \mathrm{mmc}$ & $\begin{array}{l}a=0.473-0.483 \\
c=0.772-0.786\end{array}$ & $\begin{array}{l}\mathrm{Fe}_{2} \mathrm{Mo} ; \mathrm{Fe}_{2} \mathrm{Nb} ; \mathrm{Fe}_{2} \mathrm{Ta} ; \\
\mathrm{Fe}_{2} \mathrm{Ti}_{;} ; \mathrm{Fe}_{2} \mathrm{~W}\end{array}$ & $\begin{array}{lcc}\text { AISI } & 316 ; & \text { AISI } \\
\text { 316L; } & \text { AISI } & 321 ; \\
\text { AISI } 347 & \end{array}$ \\
\hline G & fcc & 116 & Fd3m & $a=1.115-1.120$ & $\begin{array}{l}\mathrm{Ni}_{16} \mathrm{Nb}_{6} \mathrm{Si}_{7} ; \quad \mathrm{Ni}_{16} \mathrm{Ti}_{6} \mathrm{Si}_{7} ; \\
(\mathrm{Ni}, \mathrm{Fe}, \mathrm{Cr})_{16}(\mathrm{Nb}, \mathrm{Ti})_{6} \mathrm{Si}_{7}\end{array}$ & $\begin{array}{l}\text { AISI 308; AISI } \\
310 \mathrm{~S} ; \text { AISI 329; } \\
\text { Fe-20Cr-25Ni-Nb } \\
\end{array}$ \\
\hline$R$ & hex. & $\begin{array}{l}53 \\
(159)\end{array}$ & R3 & $\begin{array}{l}a=1.090 \\
c=1.934\end{array}$ & $\begin{array}{l}\mathrm{Fe} \mathrm{Fe}_{22} \mathrm{Mo}_{18} \mathrm{Cr}_{13} ; \\
\left(\mathrm{Fe}, \mathrm{Ni}_{10} \mathrm{Cr}_{5} \mathrm{Mo}_{3} \mathrm{Si}_{2}\right.\end{array}$ & $\begin{array}{l}\text { Duplex Fe-22Cr- } \\
\text { 8Ni-3Mo; } \\
\text { Superaustenitic } \\
\text { UNS S32654; } \\
\text { Maraging Fe-12Cr- } \\
\text { 9Ni-4Mo } \\
\end{array}$ \\
\hline $\begin{array}{l}\mathrm{Mu} \\
(\mu)\end{array}$ & $\begin{array}{l}\text { rhomboh } \\
\text { edral }\end{array}$ & 13 & R3m & $\begin{array}{l}a=0.4762 \\
c=2.5015\end{array}$ & $\begin{array}{l}(\mathrm{Fe}, \mathrm{Co})_{7}(\mathrm{Mo}, \mathrm{W})_{6} ; \\
(\mathrm{Cr}, \mathrm{Fe})_{7}(\mathrm{Mo})_{2}(\mathrm{Cr}, \mathrm{Fe}, \mathrm{Mo})_{4}\end{array}$ & $\begin{array}{l}\text { Fe-17Cr-14Ni-6W; } \\
\text { Fe-15Cr-40Ni-4W- } \\
\text { 2Mo-Al-Ti }\end{array}$ \\
\hline$\gamma^{\prime}$ & fcc & 4 & $\mathrm{Pm} 3 \mathrm{~m}$ & $a=0.3565-0.3601$ & $(\mathrm{Ni}, \mathrm{Co}, \mathrm{Fe}, \mathrm{Cr})_{3}(\mathrm{Al}, \mathrm{Ti})$ & $\begin{array}{l}\text { Incoloy } 800 \text { and } \\
\text { alloy A-286 }\end{array}$ \\
\hline$\gamma^{\prime \prime}$ & bct & 8 & $\begin{array}{l}\mathrm{P} 4_{2} / \mathrm{mnm} \\
14 / \mathrm{mmm}\end{array}$ & $\begin{array}{l}a=0.3624 \\
c=0.7406\end{array}$ & $\mathrm{Ni}_{3} \mathrm{Nb}$ & \begin{tabular}{|l|} 
Inconel 718 \\
\end{tabular} \\
\hline$\eta$ & hex. & 8 & $\mathrm{P}_{3} / \mathrm{mmc}$ & $\begin{array}{l}a=0.5109 \\
c=0.8299\end{array}$ & $\mathrm{Ni}_{3} \mathrm{Ti}$ & $\begin{array}{l}\text { Overaged Incoloy } \\
800 \text { and alloy A-286 }\end{array}$ \\
\hline$\delta$ & $\begin{array}{l}\text { orthorom } \\
\text { bic }\end{array}$ & 8 & Pmmn & $\begin{array}{l}a=0.5116 \\
b=0.4259 \\
c=0.4565\end{array}$ & $\mathrm{Ni}_{3} \mathrm{Nb}$ & $\begin{array}{l}\text { Overaged Inconel } \\
718\end{array}$ \\
\hline
\end{tabular}
slow kinetics: (i) carbon and nitrogen are insoluble in $\sigma$ -

Table 3. Crystal structures and compositions of intermetallic phases which may appear in austenitic stainless steels.

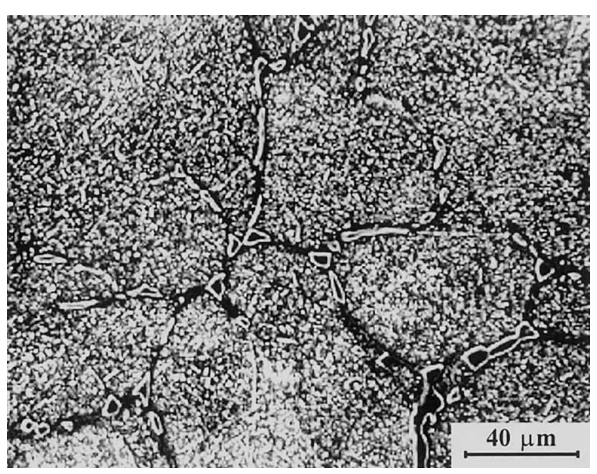

Fig. 10. Sigma phase on grain boundaries of an AISI 316 steel after $28100 \mathrm{~h}$ at $700^{\circ} \mathrm{C}$; sample was etched in V2A-Beize; scanning electron microscopy (courtesy of Michael Pohl, Ruhr-Universität Bochum, Germany). 
phase; as a consequence, $\sigma$-phase normally appears only after carbide and nitride precipitation has already taken place and the matrix is impoverished in carbon and nitrogen; (ii) its nucleation is difficult on account of its crystal structure being complex and very different from the parent austenite; and (iii) it is very rich in substitutional elements thus requiring protracted diffusion times.

Cold deformation accelerates the start of the precipitation of sigma phase particularly if there is recrystallization $^{66,25)}$ during the annealing treatment. An increase in the solution annealing temperature delays the start of sigma phase precipitation unless delta ferrite is formed during a annealing. ${ }^{25}$ In this case the sigma phase precipitation is accelerated in a subsequent aging treatment. ${ }^{67,68)}$ The rate of $\sigma$-phase precipitation from ferrite is about 100 times more rapid than the rate of $\sigma$-phase precipitation directly from austenite. ${ }^{69)}$

\subsubsection{Chi Phase $(\chi)$}

Andrews ${ }^{70)}$ was the first to identify a phase with a $\alpha$-Mn type cubic structure, the $\chi$-phase, in $\mathrm{Cr}-\mathrm{Ni}-\mathrm{Mo}$ steels. Afterwards, Kasper ${ }^{71)}$ synthesized the $\chi$-phase with a composition $\mathrm{Fe}_{36} \mathrm{Cr}_{12} \mathrm{Mo}_{10}$ and studied its crystalline structure in detail. The $\chi$-phase was also found in the $\mathrm{Fe}-\mathrm{Cr}-\mathrm{Ni}-\mathrm{Ti}$ system by Hughes and Llewelyn ${ }^{72)}$ with a composition $\mathrm{Fe}_{35} \mathrm{Ni}_{3} \mathrm{Cr}_{13} \mathrm{Ti}_{7}$. Okafor and Carlson ${ }^{73)}$ showed that the chi phase exhibits a wide range of stoichiometry, extending from the ternary chi phase $\mathrm{Fe}_{36} \mathrm{Cr}_{12} \mathrm{Mo}_{10}$ to $\mathrm{Fe}_{36} \mathrm{Cr}_{12} \mathrm{Mo}_{3} \mathrm{Ti}_{7}$, accompanied by a regular increase in lattice parameter. In general the $\chi$-phase occurs for an electron/atom ratio between 6.3 and 7.8. The precipitation range of the chi phase is somewhat more narrow than that of sigma phase (550 to $900^{\circ} \mathrm{C}$ ) and depends on the Mo content of the steel.

Similarly to the $\mathrm{M}_{6} \mathrm{C}$ carbide discussed in Sec. 3.3, $\chi$ phase precipitation can only occur if molybdenum or/and titanium is present. Several investigators identified $\chi$-phase

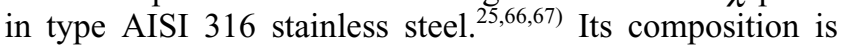
similar to that of the $\sigma$-phase, but in contrast to $\sigma$-phase, carbon can dissolve in the $\chi$-phase. Due to this property, the $\chi$-phase was classified ${ }^{49}$ in the past as a carbide-type $\mathrm{M}_{18} \mathrm{C}$. The $\chi$-phase is found to form mainly on the grain boundaries, incoherent twin boundaries, coherent twin boundaries, and on dislocations within the matrix. The $\chi$ phase exhibits ${ }^{25,66)}$ several morphologies and the following orientation relationship with austenite in the case of intragranular precipitation:

$$
\begin{aligned}
& (111)_{\gamma} / /(110)_{\chi} \\
& {[01 \overline{1}]_{\gamma} / /[\overline{1} 10]_{\chi}} \\
& {[\overline{2} 11]_{\gamma} / /[001]_{\chi}}
\end{aligned}
$$

Owing to its ability to dissolve carbon and also to its easier nucleation, $\chi$ phase precipitation, when it occurs, precedes $\sigma$-phase formation. Increased solution treatment temperatures do not seem to affect the nucleation of $\chi$ phase, but its nucleation is accelerated by cold work. ${ }^{25)}$ The $\chi$ phase has been less studied than the $\sigma$ phase, nonetheless its presence is also considered to be detrimental to the steel properties.

\subsubsection{Laves Phases $(\eta)$}

There are three kinds of Laves phases, all with stoichiometry $\mathrm{A}_{2} \mathrm{~B}$ : $\mathrm{C} 14\left(\mathrm{MgZn}_{2}\right.$ type); $\mathrm{C} 15\left(\mathrm{Cu}_{2} \mathrm{Mg}\right.$ type $)$ and $\mathrm{C} 36\left(\mathrm{MgNi}_{2}\right.$ type). The Laves phases that occur more often in the austenitic stainless steels have an hexagonal closepacked structure of $\mathrm{MgZn}_{2}$ type. The most common are $\mathrm{Fe}_{2} \mathrm{Mo}, \mathrm{Fe}_{2} \mathrm{Nb}$ and $\mathrm{Fe}_{2} \mathrm{Ti}$, or a combination of all three, for example, $\mathrm{Fe}_{2}(\mathrm{Mo}, \mathrm{Nb}, \mathrm{Ti})$. Zirconium also forms Laves phase with iron, with a fcc crystal structure of $\mathrm{Cu}_{2} \mathrm{Mg}$ type. Vanadium on the other hand does not. Those phases were initially studied in the thirties by F. Laves and should exhibit an ideal ratio of atomic radii $r_{\mathrm{B}} / r_{\mathrm{A}}$ equal to 1.225 . Nonetheless ratios within the range of 1.10 to 1.46 can be found. It is certain that electronic factors in addition to geometric factors also have an influence in the formation of the Laves phases. In the Fe-Mo system the atomic radius ratio is close to 1.10 and in spite of that $\mathrm{Fe}_{2} \mathrm{Mo}$ occurs. Whereas in the $\mathrm{Ni}-\mathrm{Nb}$ system in which the atomic radius ratio is 1.18 , closer to the ideal value, $\mathrm{Ni}_{2} \mathrm{Nb}$ has not been observed. The Laves phases occur for electron/atom ratios between 6.33 and 8.0. The Laves phase is generally stable below ${ }^{25)} 815^{\circ} \mathrm{C}$, but this strongly depends on the Mo, $\mathrm{Nb}$ and Ti contents.

The Laves phase of $\mathrm{Fe}_{2} \mathrm{Mo}$ type was found ${ }^{25,74)}$ in AISI 316 stainless steels with molybdenum contents between 2 and $3 \mathrm{wt} \%$ for long annealing times. For Ti stabilized steels it is possible ${ }^{75)}$ to avoid precipitation of $\mathrm{Fe}_{2} \mathrm{Ti}$ and $\mathrm{Ni}_{3} \mathrm{Ti}$ for $\mathrm{Ti}$ contents in solid solution up to $0.5 \mathrm{wt} \%$. This amount corresponds to an excess in relation to the stoichiometric amount of Ti needed to combine with all available carbon, forming TiC. In this regard, the niobium content is particularly critical. An excess of only $0.07 \mathrm{wt} \%$ niobium in relation to the stoichiometric content leads to precipitation of $\mathrm{Fe}_{2} \mathrm{Nb}$ for long annealing times. ${ }^{76}$ )

The $\mathrm{Fe}_{2} \mathrm{Nb}$ Laves phase precipitation ${ }^{77-80)}$ can cause significant precipitation hardening and exhibits the following orientation relationship with the austenitic matrix:

$$
\begin{gathered}
\{111\}_{\gamma} / /\{0001\}_{\mathrm{Fe}_{2} \mathrm{Nb}} \\
{[\overline{1} 10]_{\gamma} / /[10 \overline{1} 0]_{\mathrm{Fe}_{2} \mathrm{Nb}}}
\end{gathered}
$$

During aging of austenitic stainless steels with an excess of niobium $\mathrm{Fe}_{2} \mathrm{Nb}$ precipitation follows the sequence ${ }^{77,80)}$ : first it appears at grain boundaries, next at incoherent twin boundaries coherent twin boundaries and finally within the grain. The grain boundary precipitates can coarsen, forming roughly rounded shapes. In contrast, the almost continuous precipitate films on coherent twin boundaries show considerable resistance to coarsening. ${ }^{80)}$

\subsubsection{Other TCP Phases: $\mathrm{G}, \mathrm{R}$ and $\mathrm{Mu}(\mu)$}

The $\mathrm{G}, \mathrm{R}$ and $\mathrm{mu}(\mu)$ phases occur much less frequently and in smaller quantities in stainless steels than the $\sigma, \chi$ and Laves phases.

The $\mathrm{G}$ phase is a silicide of $\mathrm{Ni}_{16} \mathrm{Ti}_{6} \mathrm{Si}_{7}, \mathrm{Ni}_{16} \mathrm{Nb}_{6} \mathrm{Si}_{7}$ or $(\mathrm{Ni}, \mathrm{Fe}, \mathrm{Cr})_{16}(\mathrm{Nb}, \mathrm{Ti})_{6} \mathrm{Si}_{6}$ type. It has a complex fcc crystalline structure. Both in austenitic stainless steels ${ }^{81,82)}$ containing $\delta$ ferrite, such as low carbon AISI 310 and also AISI 308, or in duplex stainless steels, ${ }^{83)}$ such as AISI 329, the $\mathrm{G}$ phase precipitates in ferrite between 250 and $500^{\circ} \mathrm{C}$. The orientation relationship between $\mathrm{G}$ phase and ferrite most commonly found is ${ }^{83)}$ :

$$
\begin{aligned}
& (001)_{\mathrm{G}} / /(001)_{\alpha} \\
& (110)_{\mathrm{G}} / /(110)_{\alpha} \\
& (111)_{\mathrm{G}} / /(111)_{\alpha}
\end{aligned}
$$

In a low carbon fully austenitic matrix, ${ }^{84)}$ as in $\mathrm{Fe}-$ $20 \% \mathrm{Cr}-25 \% \mathrm{Ni}-\mathrm{Nb}$, the $\mathrm{G}$ phase precipitates at grain boundaries and within the grains during aging at higher temperatures than in ferrite: 500 and $850^{\circ} \mathrm{C}$. The $\mathrm{G}$ phase composition was determined by EDX analysis in this steel after annealing for $50 \mathrm{hr}$ at $650^{\circ} \mathrm{C}$. The result was (in wt\%): $51 \mathrm{Ni} ; 29 \mathrm{Nb} ; 14 \mathrm{Si} ; 4.5 \mathrm{Fe}$ and $1.5 \mathrm{Cr}$. The transformation 
of $\mathrm{NbC}$ in $\mathrm{G}$ phase was also studied in high carbon modified-HP austenitic steels. ${ }^{85)}$ Neutron irradiation can induce $\mathrm{G}$ phase precipitation in austenitic stainless steels. ${ }^{86)}$

The $\mathrm{R}$ phase basically contains $\mathrm{Mo}-\mathrm{Fe}-\mathrm{Cr}$ and has a complex hexagonal crystalline structure. It has $\mathrm{Mo}, \mathrm{Fe}$ and $\mathrm{Si}$ contents comparable to that of the $\mathrm{Fe}_{2} \mathrm{Mo}$ Laves phase, but higher $\mathrm{Cr}$ contents. The $\mathrm{R}$ phase was found both in a $\mathrm{Fe}-22 \mathrm{wt} \% \mathrm{Cr}-8 \mathrm{wt} \% \mathrm{Ni}-3 \mathrm{wt} \% \mathrm{Mo}$ duplex stainless steel $^{87)}$ and in a Fe-3wt $\% \mathrm{Mn}-24 \mathrm{wt} \% \mathrm{Cr}-22 \mathrm{wt} \% \mathrm{Ni}-7.3 \mathrm{wt} \% \mathrm{Mo}-$ $0.5 \mathrm{wt} \% \mathrm{~N}$ superaustenitic steel. ${ }^{88)}$ In the duplex steels the $\mathrm{G}$ phase was found ${ }^{87)}$ after aging between 550 and $600^{\circ} \mathrm{C}$ for $24 \mathrm{~h}$, with the following orientation relationships:

$$
\begin{aligned}
& \{30 \overline{3} 0\}_{\mathrm{R}} / /\{110\}_{\alpha} \\
& \langle 0001\rangle_{\mathrm{R}} / /\langle 1 \overline{11}\rangle_{\alpha}
\end{aligned}
$$

In the superaustenitic steel the $\mathrm{R}$ phase was found ${ }^{88)}$ in the heat affected zone of welds, in regions that reached temperatures above $800^{\circ} \mathrm{C}$. The $\mathrm{R}$ phase has been found ${ }^{89)}$ in a $\mathrm{Fe}-12 \mathrm{wt} \% \mathrm{Cr}-9 \mathrm{wt} \% \mathrm{Ni}-4 \mathrm{wt} \% \mathrm{Mo}$ maraging stainless steel after isothermal tempering at $550^{\circ} \mathrm{C}$ for $100 \mathrm{~h}$.

The $\mathrm{mu}(\mu)$ phase is found in the ternary $\mathrm{Fe}-\mathrm{Cr}-\mathrm{Mo}^{90)}$ and $\mathrm{Fe}-\mathrm{Cr}-\mathrm{W}^{91)}$ equilibrium diagrams. However the Mo and/or W contents of most austenitic stainless steels are not high enough to cause the formation of the mu phase. The mu phase formulae in Fe-Mo and $\mathrm{Fe}-\mathrm{W}$ systems are $\mathrm{Fe}_{7} \mathrm{Mo}_{6}$ and $\mathrm{Fe}_{7} \mathrm{~W}_{6}$, respectively. In ternary systems the mu phase is better represented by ${ }^{90,91)}:(\mathrm{Cr}, \mathrm{Fe})_{7}(\mathrm{Mo}, \mathrm{W})_{2}(\mathrm{Cr}$, $\mathrm{Fe}, \mathrm{Mo}, \mathrm{W})_{4}$. Matsuo and coworkers ${ }^{92)}$ studied the $\mathrm{Fe}-$ $0.01 w t \% \mathrm{C}-0.4 \mathrm{wt} \% \mathrm{Si}-1.5 \mathrm{wt} \% \mathrm{Mn}-17 \mathrm{wt} \% \mathrm{Cr}-14 \mathrm{wt} \% \mathrm{Ni}$ alloy with $\mathrm{W}$ contents up to $12 \mathrm{wt} \%$. Above $5 \mathrm{wt} \% \mathrm{~W}$ they found intergranular precipitation of $\mu$ phase that decreased the creep resistance of the material. Small amounts of grain boundary $\mu$ phase in the low carbon $\mathrm{Fe}-15 \mathrm{Cr}-40 \mathrm{Ni}-4 \mathrm{~W}-$ 2Mo-2.5Ti-2Al type alloy caused loss of impact toughness at ambient temperature. ${ }^{93)}$ The ( phase initially precipitated preferentially at grain boundaries, but after long times the $\mu$ phase was seen to precipitate both at grain boundaries and within the grains. ${ }^{93)}$

\subsection{Geometrically Close Packed Phases (GCP Phases)}

As mentioned before, the GCP phases mainly occur in nickel based alloys and their appearance in iron base alloys, especially in stainless steels, only takes place in some particular cases.

The phases that can form a coherent or semicoherent uniform particle dispersion with its consequent precipitation hardening effect in superalloys are the ordered fcc $\gamma^{\prime}$ $\mathrm{Ni}_{3}(\mathrm{Al}, \mathrm{Ti})$ and the ordered body-centered tetragonal $\gamma^{\prime \prime}$ $\mathrm{Ni}_{3} \mathrm{Nb}$. The $\eta-\mathrm{Ni}_{3} \mathrm{Ti}$ and $\delta-\mathrm{Ni}_{3} \mathrm{Nb}$ phases usually form due to overaging and are not as effective as $\gamma^{\prime}$ and $\gamma^{\prime \prime}$ for precipitation hardening and are often associated with a decrease in toughness. The most important class of iron-base superalloys comprises those alloys that are strengthened by precipitation of $\gamma^{\prime}$ in fcc matrixes, such as Incoloy 800, Incoloy 801, Incoloy 802 and alloy A-286. The 800 series Incoloys 800 are alloys with basic composition: $\mathrm{Fe}-$ $21 \mathrm{wt} \% \mathrm{Cr}-32 \mathrm{wt} \% \mathrm{Ni}$ plus $\mathrm{Ti}$ and $\mathrm{Al}$ additions. These alloys are susceptible to $\gamma^{\prime}$ and $\eta-\mathrm{Ni}_{3} \mathrm{Ti}$ precipitation. ${ }^{94)}$ The A286 superalloy has a basic composition: $\mathrm{Fe}-15 \mathrm{Cr}-26 \mathrm{Ni}-$ $1.25 \mathrm{Mo}$ and also contains $\mathrm{Ti}$ and $\mathrm{Al}$ additions. Likewise, the 800 series alloys are also susceptible to $\gamma^{\prime}$ and $\eta-\mathrm{Ni}_{3} \mathrm{Ti}$ precipitation. Whitcroft and Martin ${ }^{95)}$ studied a series of four aluminum free austenitic steels containing $2 \mathrm{wt} \% \mathrm{Ti}$ and $25 \mathrm{wt} \% \mathrm{Ni}$, with chromium contents ranging from $4 \%$ to $17 \%$ and found $\gamma^{\prime}-\mathrm{Ni}_{3} \mathrm{Ti}$ in every alloy after aging at $750^{\circ} \mathrm{C}$. The iron-containing alloy Inconel 718 (contains
Table 4. Crystal structures and compositions of nitrides, borides and sulfides which may appear in austenitic

\begin{tabular}{|c|c|c|c|c|c|c|}
\hline Phase & Unit cell & $\begin{array}{l}\text { Atoms } \\
\text { per cell }\end{array}$ & $\begin{array}{l}\text { Space } \\
\text { group }\end{array}$ & $\begin{array}{l}\text { Lattice parameters } \\
(\mathrm{nm})\end{array}$ & Composition & Occurrence \\
\hline $\mathrm{MN}$ & ord fcc & 8 & $\mathrm{Fm} 3 \mathrm{~m}$ & $a=0.4097-0.4577$ & $\begin{array}{l}\mathrm{ZrN} ; \mathrm{TiN} ; \\
\mathrm{NbN} ; \mathrm{VN}\end{array}$ & AISI 321 \\
\hline $\mathrm{M}_{2} \mathrm{~N}$ & hexagonal & 9 & P31m & $\begin{array}{l}a=0.478-0.480 \\
c=0.444-0.447\end{array}$ & $(\mathrm{Cr}, \mathrm{Fe})_{2} \mathrm{~N}$ & $\begin{array}{l}\text { AISI } 304+\mathrm{N} \\
\text { AISI } 316+\mathrm{N}\end{array}$ \\
\hline Z-phase & tetragonal & 6 & $\mathrm{P} 4 / \mathrm{nmm}$ & $\begin{array}{l}a=0.3037 \\
c=0.7391\end{array}$ & CrNNb & AISI $347+N$ \\
\hline $\mathrm{M}_{2} \mathrm{~B}$ & $\begin{array}{l}\text { orthorhom } \\
\text { bic }\end{array}$ & 48 & Fddd & $\begin{array}{l}a=1.4585 \\
b=0.7331 \\
c=0.4223\end{array}$ & $\mathrm{Cr}_{1.04} \mathrm{Fe}_{0.96} \mathrm{~B}$ & AISI 304+B \\
\hline $\mathrm{M}_{3} \mathrm{~B}_{2}$ & tetragonal & 10 & $\mathrm{P} 4 / \mathrm{mbm}$ & $\begin{array}{l}a=0.5807 \\
c=0.3142\end{array}$ & $\mathrm{FeMO}_{2} \mathrm{~B}_{2}$ & AISI 316+B \\
\hline $\mathrm{M}_{4} \mathrm{C}_{2} \mathrm{~S}_{2}$ & hexagonal & 8 & $\mathrm{P}_{3} / \mathrm{mmc}$ & $\begin{array}{l}\mathrm{a}=0.320-3.39 \\
\mathrm{c}=1.118-1.210\end{array}$ & $\begin{array}{l}\mathrm{Ti}_{4} \mathrm{C}_{2} \mathrm{~S}_{2} \\
\mathrm{Z}_{4} \mathrm{C}_{4} \mathrm{~S}_{2}\end{array}$ & AISI 321 \\
\hline
\end{tabular}
stainless steels.

only about $18.5 \%$ iron) is considered a nickel-base superalloy and is hardened by $\gamma^{\prime \prime}-\mathrm{Ni}_{3} \mathrm{Nb}{ }^{96)}$ In this alloy the appearance of $\delta-\mathrm{Ni}_{3} \mathrm{Nb}$ is a result of overaging.

\section{Other Phases: Nitrides, Borides and Sulfides}

Austenitic stainless steels normally have residual contents of $\mathrm{N}, \mathrm{B}$ and $\mathrm{S}$. In some cases these elements are added to obtain certain special properties. The low solubility of those elements in $\mathrm{Fe}-\mathrm{Cr}-\mathrm{Ni}$ austenite is the main cause for nitrides, borides and sulfides often being observed (see Table 4).

\subsection{Nitrides}

Nitrides that form in austenitic stainless steels can be grouped in two classes: (i) primary nitrides of type $\mathrm{MN}$ $(\mathrm{M}=\mathrm{Zr}, \mathrm{Ti}, \mathrm{Nb}$ and $\mathrm{V})$ formed in stabilized steels containing residual amounts of nitrogen $(<0.1 \mathrm{wt} \%)$; and (ii) secondary nitrides of the type $\mathrm{M}_{2} \mathrm{~N}(\mathrm{M}=\mathrm{Cr}, \mathrm{Fe})$, which precipitate in stainless steels containing high levels of nitrogen $(0.1$ to $0.9 \mathrm{wt} \%)$. Nitrogen is added to stainless steels because it improves mechanical properties and corrosion resistance, and also because it is a strong austenite stabilizer.

The MN nitrides have the same crystalline structure as MC carbides, but they are even more stable and do not dissolve during solution annealing. These nitrides are usually sub-stoichiometric $\left(\mathrm{MN}_{1-X}\right)$ and often show significant solid solubility among themselves. ${ }^{97}$ ) They can dissolve small amounts of other metallic elements present in the matrix, such as $\mathrm{Fe}, \mathrm{Cr}$ and $\mathrm{Ni}$, but only very small amounts of carbon can be dissolved as carbon increases their unit cell and lattice parameter. Due to the high stability and consequent low solubility of these nitrides, almost all nitrogen forms nitrides, particularly in Ti stabilized steels. These nitrides $^{29)}$ have a faceted morphology and their size is typically $10-15 \mu \mathrm{m}$.

On the other hand, the maximum solubility of nitrogen $^{98-100)}$ in $\mathrm{Fe}-\mathrm{Cr}-\mathrm{Ni}$ or $\mathrm{Fe}-\mathrm{Cr}-\mathrm{Mn}-\mathrm{Ni}$ austenites is about $0.9 \mathrm{wt} \%$. This solubility decreases considerably with temperature below $1000^{\circ} \mathrm{C} .^{98-100)}$ The $(\mathrm{Cr}, \mathrm{Fe})_{2} \mathrm{~N}$ nitrides can precipitate continuously or discontinuously. ${ }^{100,101)}$ Chromium nitride precipitation in austenitic stainless steels with commercial levels $(<0.1 \mathrm{wt} \%)$ of nitrogen usually occurs in a continuous mode on grain boundaries, inside the grains and at dislocations. Discontinuous precipitation of chromium nitride is not a common observation in this class of steels. This kind of discontinuous precipitation was only observed in some austenitic stainless steels, especially in austenitic stainless steels with very high nitrogen content. Nitrogen depletion of the matrix due to precipitation of nitrides can make austenite unstable and it can make possible the formation of ferrite and sigma phase at aging tempera- 
tures. ${ }^{100)}$ Finally, nitrogen in solid solution delays the precipitation of phases which do not dissolve or dissolve very little nitrogen, such as $\mathrm{M}_{23} \mathrm{C}_{6}, \sigma, \chi$ and Laves phase. ${ }^{26,102)}$

The $\mathrm{Z}$ phase is a nitride that forms in stainless steels containing niobium and more than $0.4 \mathrm{wt} \%$ nitrogen. ${ }^{103)}$ The $Z$ phase was detected first by Hughes and Andrews ${ }^{104)}$ in $\mathrm{Fe}-18 \mathrm{Cr}-\mathrm{Ni}-\mathrm{Nb}$ steels after creep testing in the range 750 to $850^{\circ} \mathrm{C}$. Its occurrence was first reported by Hugues and Andrews in 1957 in the discussion to Hagel and Beattie ${ }^{105}$ ) paper. After some initial controversy, its crystalline structure was determined by Jack and Jack ${ }^{106)}$ to be tetragonal (space group $\mathrm{P} 4 / \mathrm{nmm}$ ). In addition to $\mathrm{Cr}, \mathrm{N}$ and $\mathrm{Nb}$ the $\mathrm{Z}$ phase can also contain Mo. ${ }^{103)}$ In niobium stabilized stainless steels, whenever the $Z$ phase forms so does $\mathrm{NbC}$, which is probably more stable than the $Z$ phase. ${ }^{107)}$ The $Z$ phase precipitation can take place within a wide temperature range from 600 to $1200^{\circ} \mathrm{C}$. It forms on grain boundaries and within grains with different morphologies. The orientation relationship between austenite and $\mathrm{Z}$ phase found is ${ }^{103)}$ :

$$
\begin{aligned}
& (001)_{\gamma} / /(001)_{\mathrm{Z}} \\
& {[100]_{\gamma} / /[1 \overline{1} 0]_{\mathrm{Z}}}
\end{aligned}
$$

\subsection{Borides}

The positive influence of small additions, $10-80 \mathrm{ppm}$, of boron on the creep behavior and hot workability of austenitic stainless steels is well established. Nonetheless, if boron content is too high it may cause the formation of a low-melting point $\left(1150-1225^{\circ} \mathrm{C}\right)$ eutectic, which may cause hot shortness during hot working and welding. Boron forms an eutectic: $\mathrm{L} \rightarrow \gamma+(\mathrm{Cr}, \mathrm{Fe})_{2} \mathrm{~B}$ with the $\mathrm{Fe}-\mathrm{Cr}-\mathrm{Ni}$ austenitic alloys. The eutectic temperature is not much higher than $1200^{\circ} \mathrm{C}$ for $2 \mathrm{wt} \% \mathrm{~B}$. The maximum solubility of boron in austenite for a $\mathrm{Fe}-16 \mathrm{wt} \% \mathrm{Cr}-13 \mathrm{wt} \% \mathrm{Ni}$ steel is about $200 \mathrm{ppm}$ at the eutectic temperature and decreases to about $20 \mathrm{ppm}$ below $900^{\circ} \mathrm{C}{ }^{108)}$ These results were confirmed by Goldschmidt ${ }^{109,110)}$ in $\mathrm{Fe}-20 \mathrm{wt} \% \mathrm{Cr}-25 \mathrm{wt} \% \mathrm{Ni}$ and $\mathrm{Fe}-18 \mathrm{wt} \% \mathrm{Cr}-15 \mathrm{wt} \% \mathrm{Ni}$ steels.

When held between 650 and $1050^{\circ} \mathrm{C}$, stainless steels containing more than about $30 \mathrm{ppm}$ of boron are susceptible to the precipitation of two types of orthorhombic borides: $(\mathrm{Cr}, \mathrm{Fe})_{2} \mathrm{~B}$ and $(\mathrm{Cr}, \mathrm{Fe}, \mathrm{Mo})_{3} \mathrm{~B}_{2}$. The $\mathrm{M}_{2} \mathrm{~B}$ is found more frequently and the $\mathrm{M}_{3} \mathrm{~B}_{2}$ occurs only in steels with higher molybdenum contents. $\left.{ }^{111}\right)$ The $(\mathrm{Cr}, \mathrm{Fe})_{2} \mathrm{~B}$ phase precipitates chiefly on the grain boundaries. ${ }^{112,113)}$ When it precipitates within the grain it is often found to form at the incoherent phase boundaries of primary carbides. The beneficial effects of boron are normally associated with boron in solid solution. The volume fraction of borides is very small and has no significant effect on mechanical properties. Notwithstanding in nuclear applications the amount and the distribution of boron are important. The reason for this is that the B-10 isotope can react with neutrons producing helium, which causes high-temperature embrittlement. ${ }^{112)}$

\subsection{Sulfides}

Kaneko and coworkers ${ }^{114)}$ determined the following sequence of thermodynamic stability for the sulfide forming elements in steels: $\mathrm{Zr}>\mathrm{Ti}>\mathrm{Mn}>\mathrm{Nb}>\mathrm{V}>\mathrm{Cr} \mathrm{Al}>\mathrm{Mo}>\mathrm{W}>$ $\mathrm{Fe}>\mathrm{Ni}>\mathrm{Co}>\mathrm{Si}$. Da Casa and Nileshwar ${ }^{115)}$ confirmed the large affinity between $\mathrm{Ti}$ and sulfur. They found titanium sulfides in an AISI 321 steel with S contents as low as $20 \mathrm{ppm}$ (in wt\%). The high frequency with which Ti sulfides are found and identified in Ti stabilized ${ }^{29,32,33,115,116)}$ austenitic stainless steels seem to confirm this. These sul- fides form during solidification. They are fractured and redistributed during mechanical work. For this reason they appear ${ }^{29)}$ in groups of aligned particles roughly 2 to $5 \mu \mathrm{m}$ in size.

Although it is now known that the crystalline structure of Ti sulfide is hexagonal, there was initially some doubt about its structure, composition and representation. Gemmil and coworkers ${ }^{117)}$ found Ti sulfide for the first time in Ti stabilized austenitic stainless steels and called it Y phase. These authors ${ }^{117)}$ suggested that the Y phase would be a structural modification of TiN and indexed it as a hexagonal structure. Later, Brown and coworkers ${ }^{118)}$ in a similar alloy extracted a phase that when chemically analyzed, contained sulfur. This phase had diffraction peaks that agreed well with those found by Gemmil ${ }^{117)}$ for the Y phase. They called it $\tau$ phase and suggested the formula $\mathrm{Ti}_{2} \mathrm{~S}$. After this, Frick and Rhode ${ }^{119}$ ) and Kudielka and Rhode $^{120)}$ showed that the hexagonal structure of $\mathrm{Ti}_{2} \mathrm{~S}$ and $\mathrm{Zr}_{2} \mathrm{~S}$ could become more compact and more stable by the dissolution of carbon. These authors suggested that the formulae $\mathrm{Ti}_{4} \mathrm{C}_{2} \mathrm{~S}_{2}$ and $\mathrm{Zr}_{4} \mathrm{C}_{2} \mathrm{~S}_{2}$ better represented the composition of these sulfides or carbosulfides.

\section{Time-Temperature-Precipitation Diagrams}

The time-temperature-transformation/precipitation (TTT/ TTP) diagrams together with the continuous-cooling-transformation/precipitation (CCT/CCP) diagrams have been used for over seventy years to represent the kinetics of phase transformations in steels to guide heat-treating. ${ }^{121)}$ In the case of austenitic stainless steels, the final heat-treatment before use is often solution annealing, particularly in the non-stabilized austenitic stainless steels. So, for these steels, the TTT/TTP diagrams are mainly used to represent the sequence of precipitation and the competition among different phases. The available diagrams for these steels are normally isothermal TTT diagrams and only show the curves corresponding to the start of the precipitation. As the austenite in these steels is far more stable than the austenite in low carbon steels, the martensite start $\left(M_{\mathrm{s}}\right)$ and finish $\left(M_{\mathrm{f}}\right)$ lines are located at low temperatures are not usually show in these diagrams.

The microstructure of the austenitic stainless steels at room temperature following rapid cooling from the solution annealing temperature consists primarily of a low stacking fault energy polycrystalline matrix ${ }^{122-124)}$ and the wrought materials present high frequency of annealing twins. ${ }^{125)}$ The solution annealing heat-treatment is carried out around $1050^{\circ} \mathrm{C}$, because higher solution temperatures may cause abnormal grain growth, particularly in the stabilized steels. ${ }^{126)}$ However, even after rapid cooling austenite is rarely the only phase present. The most common phases present after the solution annealing heat treatment are $\mathrm{Ti}(\mathrm{N}, \mathrm{C}), \mathrm{TiC}, \mathrm{Nb}(\mathrm{C}, \mathrm{N}), \mathrm{Ti}_{4} \mathrm{C}_{2} \mathrm{~S}_{2}$ and oxide inclusions containing variable contents of silicon, chromium, niobium, titanium and aluminum. The total volume fraction of these phases after the solution annealing is usually less than $0.5 \mathrm{vol} \%$. After precipitation the total volume fraction of non-austenitic phases is usually less than $10 \mathrm{vol} \% .^{25,29,32)}$

Carbide and nitride (in the high $\mathrm{N}$ steels) precipitation precedes the precipitation of intermetallic phases. The precipitation of $\mathrm{M}_{23} \mathrm{C}_{6}$ on the grain boundaries almost always takes place first. A comparison between the curve for the start of $\mathrm{M}_{23} \mathrm{C}_{6}$ with that for the MC in the stabilized steels reveals that the MC start curve is located at higher temperatures and longer times. ${ }^{29,127)}$ The upper part of both curves 


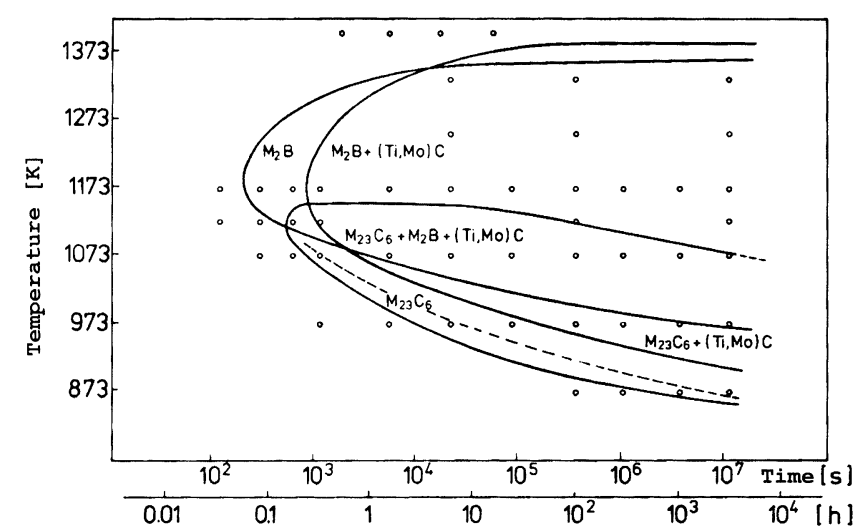

Fig. 11. Time-temperature-precipitation diagram of the DIN W. Nr. 1.4970 austenitic stainless steel solution annealed for $30 \mathrm{~min}$ at $1130^{\circ} \mathrm{C}$ and water quenched prior to aging (after A. F. Padilha, USP, Brazil). The stability regions of the various precipitated phases are represented by $\mathrm{C}$ curves.

cross at about $850^{\circ} \mathrm{C}$. For this reason in stabilized steels it is usual practice to carry out a precipitation heat-treatment after solution annealing, a stabilization heat treatment. This treatment is carried out between 850 and $900^{\circ} \mathrm{C}$ to induce the precipitation of $\mathrm{MC}$ carbides and reduce the risk of occurrence of intergranular corrosion due to the precipitation of $\mathrm{M}_{23} \mathrm{C}_{6}$ (see Fig. 11).

The $\mathrm{M}_{6} \mathrm{C}$ precipitation depends on the presence of Mo and $\mathrm{Nb}$ in the steels and only takes place for long times and in small amounts. Figure 11 shows $^{29}$ the TTT diagram of a $\mathrm{Fe}-15 \mathrm{wt} \% \mathrm{Cr}-15 \mathrm{wt} \% \mathrm{Ni}-1.2 \mathrm{wt} \% \mathrm{Mo} \mathrm{Ti}$ stabilized austenitic steel containing $45 \mathrm{ppm}$ (in wt\%) of boron. Notice that in this alloy the precipitation of intermetallic phases and of $\mathrm{M}_{6} \mathrm{C}$ did not occur. ${ }^{29,128)}$ The primary phase TiN, (Ti, Mo)C and $\mathrm{Ti}_{4} \mathrm{C}_{2} \mathrm{~S}_{2}$, that remained after the solution annealing are not shown in the diagram. The mentioned low boron content was enough to cause a boride precipitation.

The precipitation of intermetallic phases takes place after precipitation of carbides and nitrides due to the following factors: (i) the intermetallic phase, sigma and Laves in particular, do not dissolve carbon and nitrogen; (ii) the diffusivities of the substitutional elements that form these phases are low; (iii) the orientation relationship of these phases with austenite are not favorable for their nucleation, especially for sigma phase. These same arguments can explain why the chi phase precipitation can precede sigma phase precipitation, as mentioned in Sec. 4.1.2. It is believed that chi phase may dissolve carbon and moreover shows more favorable orientation relationships with the austenite than sigma. The chi phase precipitation depends also on the presence of Mo and/or Ti in the steel, and Laves phase precipitation depends on the presence of $\mathrm{Mo}, \mathrm{Nb}$ and/or $\mathrm{Ti}$. The sigma phase is the only intermetallic phase among the three mentioned above that occurs in the binary $\mathrm{Fe}-\mathrm{Cr}$ system. In the steels containing Mo and/or Ti, precipitation of Laves phase occurs below $850^{\circ} \mathrm{C}$. The presence of $\mathrm{Nb}$ significantly increases the highest temperature in which sigma and Laves phase can form, increasing it to about $\left.950^{\circ} \mathrm{C} .{ }^{129}\right)$ According to Lai, ${ }^{74)}$ below $700^{\circ} \mathrm{C}$ the precipitation of sigma phase in an AISI 316 steel takes place after Laves $(\eta)$ phase precipitation is finished. The Laves phase nucleates predominantly on dislocations while the sigma phase nucleates mainly on grain boundaries. ${ }^{70)}$ Figure 12 shows $^{25)}$ the TTT diagram of an AISI 316 steel. It is interesting to point out that, in this case, the steel contained only $2.05 \mathrm{wt} \% \mathrm{Mo}$ and

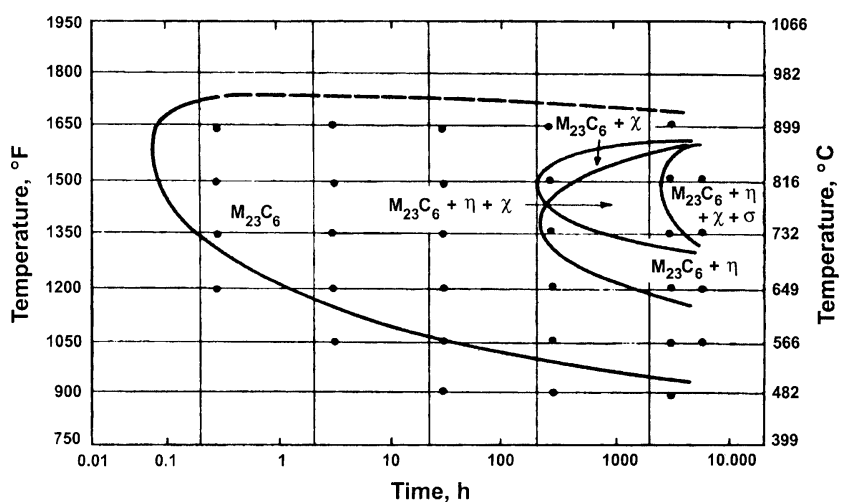

Fig. 12. Time-temperature-precipitation diagram of the AISI 316 austenitic stainless steel solution annealed for $1.5 \mathrm{~h}$ at $1260^{\circ} \mathrm{C}$ and water quenched prior to aging (after Ref. 25)). The stability regions of the various precipitated phases are represented by C-curves. $\sigma=$ sigma phase, $\chi=$ chi phase, $\eta=$ eta phase (Laves phase).

$\mathrm{M}_{6} \mathrm{C}$ was not found. ${ }^{25)}$ In the same work, another AISI 316 $\mathrm{L}$ steel with $2.66 \mathrm{wt} \% \mathrm{Mo} \mathrm{M}_{6} \mathrm{C}$ could also be found.

Only a very limited number of TTP diagrams are available. The main reason for this is probably the complexity of the precipitation reactions in these steels that require a large amount of work for the determination of such a diagram.

\section{Martensite Formation}

Austenite in stainless steels in general and the austenite in the 300 steels series in particular is not a stable phase. In the solution-treated condition, the $\mathrm{M}_{\mathrm{s}}$ temperature is normally below room temperature. The $M_{d}$ temperature, the temperature below which martensite will form under deformation, of the majority of those steels is above room temperature. Two kinds of martensite can occur in stainless steels: $\alpha^{\prime}$ (bcc, ferromagnetic) and $\varepsilon$ (hcp, non-ferromagnetic). Transformation of austenite to martensite can be also induced in austenitic stainless steels by cathodic charging of hidrogen. ${ }^{130}$ The lattice parameters are typically:

$$
a_{\alpha^{\prime}}=0.2872 \mathrm{~nm}
$$

and

$$
a_{\varepsilon}=0.2532 \mathrm{~nm} ; \quad c_{\varepsilon}=0.4114 \mathrm{~nm}
$$

Assuming $^{131)} a_{\gamma}=0.3585 \mathrm{~nm}$, one can calculate that the $\gamma \rightarrow \alpha^{\prime}$ transformation causes a volume increase of $2.57 \%$, while the $\gamma \rightarrow \varepsilon$ transformation causes a volume decrease of $0.81 \%$. The orientation relationship between the parent phase and martensite most often reported for stainless steels are:

$$
\begin{aligned}
& (111)_{\gamma} / /(011)_{\alpha^{\prime}} \\
& {[1 \overline{1} 0]_{\gamma} / /[1 \overline{1} 1]_{\alpha^{\prime}}}
\end{aligned}
$$

and

$$
\begin{aligned}
& (111)_{\gamma} / /(0001)_{\varepsilon} \\
& {[1 \overline{1} 0]_{\gamma} / /[1 \overline{2} 10]_{\varepsilon}}
\end{aligned}
$$

\section{1 . Transformation during Cooling}

There are several empirical equations that relate the $M_{s}$ temperature to the chemical composition. Eichelman and Hull's ${ }^{132)}$ is one of the most widely used: 


$$
\begin{aligned}
\mathrm{M}_{\mathrm{s}}\left({ }^{\circ} \mathrm{C}\right)= & 1302-42(\% \mathrm{Cr})-61(\% \mathrm{Ni})-33(\% \mathrm{Mn}) \\
& -28(\% \mathrm{Si})-1667(\%[\mathrm{C}+\mathrm{N}]) \ldots \ldots \ldots \ldots \ldots . . .
\end{aligned}
$$

Equation (4) suggests that many steels in Table 1, when cooled to cryogenic temperatures, will form $\alpha^{\prime}$ martensite. The ability to form $\alpha^{\prime}$ martensite becomes greater during cooling after sensitization. $\mathrm{M}_{23} \mathrm{C}_{6}$ precipitation at the grain boundaries causes impoverishment of chromium, carbon and other alloying elements in the vicinity of the grain boundaries. This leads to a higher $\mathrm{M}_{\mathrm{s}}$ temperature, making the material more susceptible to the formation of $\alpha^{\prime}$ martensite close to the grain boundaries during cooling. ${ }^{133)}$ For $\varepsilon$ martensite no equations like Eq. (4) are reported. However it is reasonable to expect that the formation of $\varepsilon$ martensite increases with a decrease in the stacking fault energy of austenite. ${ }^{134,135)}$

\subsection{Strain Induced Transformation}

The most frequent case of martensite formation at room temperature in stainless steels is that of strain induced martensite.

The formation and the amount of $\alpha^{\prime}$ and $\varepsilon$ depend on the steel composition, on its stacking fault energy, and on the temperature, amount and rate of deformation. According to Kaieda and Oguchi, ${ }^{136)}$ the amount of $\alpha^{\prime}$ depends also on the stress state during deformation.

There are several empirical equations that relate the $M_{d}$ temperature with the chemical composition. One of the most often employed is due to Angel ${ }^{137)}$ :

$$
\begin{aligned}
\mathrm{M}_{\mathrm{d}}(30 / 50)\left({ }^{\circ} \mathrm{C}\right)= & 413-13.7(\% \mathrm{Cr})-9.5(\% \mathrm{Ni}) \\
& -8.1(\% \mathrm{Mn})-18.5(\% \mathrm{Mo})-9.2(\% \mathrm{Si}) \\
& -462(\%[\mathrm{C}+\mathrm{N}]) \ldots \ldots \ldots \ldots \ldots \ldots \ldots \ldots \ldots \ldots \ldots \ldots \ldots \ldots \ldots \ldots \ldots
\end{aligned}
$$

Where $\mathrm{M}_{\mathrm{d}}(30 / 50)\left({ }^{\circ} \mathrm{C}\right)$ is the temperature at which $50 \mathrm{vol} \%$ $\alpha^{\prime}$ is formed after a true tensile strain of $30 \%$.

For the majority of austenitic stainless steels, the $\mathrm{M}_{\mathrm{d}}$ temperature is above room temperature. For $\varepsilon$ martensite such empirical equations are not available. The susceptibility of the austenite to form martensite and the amount of martensite formed increase with a decrease in the deformation temperature. The effect of deformation rate is difficult to study because, as the deformation rate is increased, the specimen temperature is also increased due to Joule heating.

The simultaneous formation of $\alpha^{\prime}$ and $\varepsilon$ makes the understanding of their formation mechanism difficult. Mangonon and Thomas, ${ }^{138,139)}$ working with an AISI 304 stainless steels, found that for a $20 \%$ deformation at $-196^{\circ} \mathrm{C}$, the amount of $\alpha^{\prime}$ formed could reach values around $50 \mathrm{vol} \%$. During deformation, the amount of $\varepsilon$ increased until $5 \%$ of deformation and afterwards decreased. On the other hand, the amount of $\alpha^{\prime}$ increased continuously with deformation. According to those authors, ${ }^{138,139)} \alpha^{\prime}$ martensite formed preferentially at the intersections between the $\varepsilon$ plates with the twin boundaries and with grain boundaries. Those same authors further reported that $\varepsilon$ martensite could also form during cooling to low temperatures in the absence of plastic deformation, whereas for $\alpha^{\prime}$ formation deformation was necessary. Seetharaman and Krishnan, ${ }^{140)}$ working with an AISI 316 steel, also found that during deformation at low temperatures the formation of $\varepsilon$ martensite precedes the formation of $\alpha^{\prime}$. They also found that the amount of $\varepsilon$ increases with the deformation, goes through a maximum and afterwards decreases, whereas the amount of $\alpha^{\prime}$ continuously increases with deforma- tion. The results of Mongonon and Thomas ${ }^{138,139)}$ and of Seetharaman and Krishnan ${ }^{140)}$ suggest the following transformation sequence: $\gamma \rightarrow \varepsilon \rightarrow \alpha^{\prime}$; $\varepsilon$ martensite is generated from austenite, and is then transformed into $\alpha^{\prime}$ martensite; $\alpha^{\prime}$ martensite can be also directly formed from austenite.

When stainless steels containing deformation induced martensite are annealed, the martensite may revert to austenite. This reversion usually occurs at temperatures lower and for shorter times than those required for the recrystallization of the deformed stainless steel. ${ }^{141)}$ The formability of the austenitic alloys is influenced greatly by martensitic transformation during straining. ${ }^{142,143)}$ Recently, Burstein and co-workers ${ }^{144}$ showed that strain induced martensite in AISI 304L can be removed by appropriate electrochemical treatment in aqueous solutions at much lower temperatures than conventional annealing heat treatments.

\section{Acknowledgements}

The authors are grateful to Conselho Nacional de Desenvolvimento Científico e Tecnológico $(\mathrm{CNPq})$ and to FAPESP (contract 99/10796-8) for the financial support.

\section{REFERENCES}

1) B. Strauß and E. Maurer: Kruppsche Monatsh., 1 (1920), 120.

2) ASM Speciality Handbook: Stainless Steels, ed. by J. R. Davis, ASM International, Materials Park, OH, (1994), 13.

3) V. G. Rivlin and G. V. Raynor: Int. Met. Rev., 25 (1980), 21.

4) ASM Handbook, Vol. 3: Phase Diagrams, ed. by H. Baker, ASM International, Materials Park, OH, (1992).

5) H.-J. Eekstein: Korrosionbeständige Stähle, Deutscher Verlag für Grundstoffindustrie GmbH, Leipzig, (1990), 18.

6) Metals Handbook, 8th Ed.: Metallography, Structures and Phase Diagrams, Vol. 8, ASM International, Materials Park, OH, (1973), 421.

7) J. Bechtoldt and H. C. Vacher: J. Res. Natl. Bur. Stand., 58 (1957), 7.

8) E. Folkhard: Welding Metallurgy of Stainless Steels, SpringerVerlag, Wien, (1984), 1.

9) A. L. Schaeffler: Weld. J., 26 (1947), Res. Suppl., 603s.

10) A. L. Schaeffler: Iron Age, 162 (1948), 73.

11) A. L. Schaeffler: Met. Prog., 56 (1949), 680,680B.

12) Welding Handbook, Vol. 4: Metals and Their Weldability, 6th Ed., American Welding Society, Miami, Florida, (1972).

13) W. T. DeLong: Weld. J., 53 (1974,), Res. Suppl., 273s.

14) F. C. Hull: Weld. J., 52 (1973), Res. Suppl., 193s.

15) R. H. Espy: Weld. J., 61 (1982), Res. Suppl., 149s.

16) M. Schirra: Stahl Eisen, 112 (1992), 117.

17) G. K. Allan: Ironmaking Steelmaking, 22 (1995), 465.

18) H. Tuma, M. Vyclický and K. Löbl: Arch. Eisenhüttenwes., 41 (1970), 983

19) H. Gerlach: Drahtwelt, 56 (1970), 25

20) A. Westgren: Nature, 132 (1933), 480

21) P. D. Southwick and R. W. K. Honeycombe: Met. Sci., 16 (1982), 475.

22) H. J. Goldschmidt: J. Iron Steel Inst., 160 (1948), 345.

23) J. Philibert, G. Henry, M. Robert and J. Plateau: Mem. Sci. Rev. Metall., 58 (1961), 557.

24) C. Da Casa, V. B. Nileshwar and D. A. Melford: J. Iron Steel Inst., 207 (1969), 1325

25) B. Weiss and R. Stickler: Metall. Trans. A, 3 (1972), 851.

26) U. K. Mudali, P. Shankar, D. Sundararaman and R. K. Dayal: Mater. Sci. Technol., 15 (1999), 1451.

27) M. Deighton: J. Iron Steel Inst., 208 (1970), 1012.

28) J. E. Spruiell, J. Scott, C. S. Ary and R. L. Hardin: Metall. Trans. A, 4 (1973), 1533.

29) A. F. Padilha, G. Schanz and K. Anderko: J. Nucl. Mater, 105 (1982), 77.

30) M. Lagerquist and R. Lagneborg: Scand. J. Metall., 1 (1972), 81.

31) H. Kokawa, M. Shimada and Y. S. Sato: JOM, 52 (2000), No. 7, 34.

32) A. S. Grot and J. E. Spruiell: Metall. Trans. A, 6 (1975), 2023.

33) J. A. Leitnaker and Bentley: Metall. Trans. A, 8 (1977), 1605.

34) F. E. Asbury and G. Willoughby: J. Iron Steel Inst., 204 (1966), 32.

35) L. E. Toth: Transition Metal, Carbides and Nitrides, Academic Press, New York, (1971).

36) H. Holleck: Binäre und ternäre Carbid-und Nitridsysteme der Übergangsmetalle, Gebrüder Bornträger, Berlin, (1984).

37) H. O Aandrén, A. Henjered and H. Norden: J. Mater. Sci., 15 (1980), 2365.

38) T. Thorvaldsson and G. L. Dunlop: Met. Sci., 16 (1982), 184. 
39) S. R. Keown and F. B. Pickering: Proc. Conf. Creep Strength in Steel and High-Temperature Alloys, Sheffield, Metals Society, London, (1974), 134.

40) P. G. Stone, J. Orr and J. C. Guest: J. British Nucl. Energy Soc., 14 (1975), 25.

41) A. R. Jones, P. R. Howell and B. Ralph: J. Mater. Sci., 11 (1976), 1593.

42) A. R. Jones, P. R. Howell and B. Ralph: J. Mater. Sci., 11 (1976), 1600

43) L. K. Singhal and J. W. Martin: J. Iron Steel Inst., 205 (1967), 947.

44) T. Thorwaldsson and G. L. Dunlop: Proc. 5th Int. Conf. on Strength of Metals and Alloys, Vol. 1, ed. by P. Hasen, V. Gerold and G. Kostorz, Pergamon Press, Aachen, (1979), 755.

$45)$ T. Thorvaldsson and G. L. Dunlop: Met. Sci., 14 (1980), 513.

46) P. R. Howell, J. O. Nilsson and G. L. Dunlop: J. Mater. Sci., 13 (1978), 2022

47) A. C. Franker and H. H. Stadelmaier: Trans. Am. Inst. Mining Met. Eng. (AIME), 245 (1969), 847

48) H. Thier, A. Bäumel and E. Schmidtmann: Arch. Eisenhüttenwes., 40 (1969), 333

49) H. J. Goldschmidt: Interstitial Alloys, Butterworths, London, (1967).

50) C. Qiu: Steel Res., 64 (1993), 618.

51) H. Tuma, P. Gröbner and K. Löbl: Arch. Eisenhüttenwes., 40 (1969), 727

52) J. R. Gwyther, M. R. Hobdell and A. J. Hooper: Met. Technol., 1 (1974), 406.

53) H. W.-Tai and R. W. K. Honeycombe: Mater. Sci. Technol., 1 (1985), 385

54) G. D. Barbabela, L. H. de Almeida, T. L. da Silveira and I. Le May: Mater. Charact., 26 (1991), 1.

55) C. P. Tabrett, I. R. Sare and M. R. Ghomashchi: Int. Mater. Rev., 41 (1996), 59.

56) G. L. F. Powell and J. V. Bee: J. Mater. Sci., 31 (1996), 707.

57) C. T. Sims: The Superalloys, ed. by C. T. Sims and W. C. Hagel, John Wiley \& Sons, New York, (1972), 259.

58) H. J. Beattie, Jr. and W. C. Hagel: Trans. Am. Inst. Mining Met. Eng., 233 (1965), 272

59) W. Treitschke and G. Tammann: Z. Anorg. Chem., 55 (1907), 402.

60) E. C. Bain and W. E. Griffiths: Trans. Am. Inst. Mining Met. Eng., 75 (1927), 166

61) E. R. Jett and F. Foote: Metals and Alloys, 7 (1936), 207.

62) G. Bergman and D. P. Shoemaker: J. Chem. Phys., 19 (1951), 515.

$63)$ M. S. Dean and W. J. Plumbridge: Nucl. Energy, 21 (1982), 119.

64) M. H. Lewis: Acta Metall., 14 (1966), 1421.

65) F. R. Beckitt: J. Iron Steel Inst., 207 (1969), 632

66) P. Duhaj, J. Ivan and E. Makovický: J. Iron Steel Inst., 206 (1968) 1245

67) H. Wiegand and M. Doruk: Arch. Eisenhüttenwes., 33 (1962), 559.

68) L. K. Singhal and J. W. Martin: Acta Metall., 16 (1968), 1441.

69) J. Barcik: Mater. Sci. Technol., 4 (1988), 5.

70) K. W. Aandrews: Nature, 164 (1949), 1015.

71) J. S. Kasper: Acta Metall., 2 (1954), 456.

72) H. Hughes and D. T. Llewellyn: J. Iron Steel Inst., 192 (1959), 170

$73)$ I. C. I. Okafor and O. N. Carlson: Metall. Trans. A, 9 (1978), 1651

74) J. K. L. Lai: Mater. Sci. Eng., 58 (1983), 195.

75) B. Hattersley and W. Hume-Rothery: J. Iron Steel Inst., 204 (1966), 683.

76) K. Bungardt, G. Lennartz and K. Wetzlar: Arch. Eisenhüttenwes., $30(1959), 429$.

77) A. W. Denhan and J. M. Silcock: J. Iron Steel Inst., 207 (1969), 585.

78) I. Kirman: J. Iron Steel Inst., 207 (1969), 1612.

79) H.-J. Kestenbach and L. O. Bueno: Mater. Sci. Eng., 66 (1984), L19.

80) A. F. Padilha, M. Pohl and L. V. Ramanathan: Prakt. Metallogr., 31 (1994), 436.

81) A. V. Kington and F. W. Noble: Mater. Sci. Technol., 11 (1995), 268.

82) J. M. Vitek, S. A. David, D. J. Alexander, J. R. Keiser and R. K. Nanstad: Acta Metall. Mater., 39 (1991), 503.

83) A. Mateo, L. Llanes, M. Anglada, A. Redjaimia and G. Metauer: J. Mater. Sci., 32 (1997), 4533.

84) D. J. Powell, R. Pilkington and D. A. Miller: Acta Metall., 36 (1988), 713.

85) R. A. P. Ibañez, G. D. de Almeida Soares, L. H. de Almeida and I. Le May: Mater. Charact., 30 (1993), 243.

86) T. M. Williams, J. M. Titchmarsh and D. R. Arkell: J. Nucl. Mater., 107 (1982), 222.

87) J.-O. Nilsson and P. Liu: Mater. Sci. Technol., 7 (1991), 853.

88) S. Heino, E. M. Knutson-Wedel and B. Karlsson: Mater. Sci. Technol., 15 (1999), 101.

89) P. Liu, A. H. Stigenberg and J.-O. Nilsson: Acta Metall. Mater., 43 (1995), 2881
90) J.-O. Anderson and N. Lange: Metall. Trans. A, 19A (1988), 1385.

91) P. Gustafson: Metall. Trans. A, 19A (1988), 2531.

92) T. Matsuo, G. Gao, Y. Kondo and R. Tanaka: Tetsu-to-Hagané, 71 (1986), 869.

93) G. Chen, X. Xie, K. Ni, Z. Xu, M. Zhang and Y. Ju: Proc. Superalloys 80 , ed. by J. K. Tien et al., ASM, Metals Park, OH, (1980), 323.

94) P. G. Stone, J. Orr and J. C. Guest: J. British Nucl. Energy Soc., 15 (1975), 25.

95) C. S. Whitcroft and J. W. Martin: Mater. Charact., 39 (1997), 91.

96) I. Kirman and D. H. Warrington: J. Iron Steel Inst., 205 (1967), 1264.

97) P. Duwez and F. OdellL: J. Electrochem. Soc., 97 (1950), 299.

98) R. P. Reed: JOM, 41 (1989), 16

99) W. M. Small: Scr. Metall. Mater., 24 (1990), 1695.

100) I. F. Machado and A. F. Padilha: Steel Res., 67 (1996), 285

101) R. F. A. Jargelius-Pettersson: Z. Metallkd., 89 (1998), 177.

102) H. Thier, A. Bäumel and E. Schmidtmann: Arch. Eisenhüttenwes., 40 (1969), 333

103) V. Vodárek: Scr. Metall. Mater., 25 (1991), 549.

104) H. Hughes: J. Iron Steel Inst., 205 (1967), 775.

105) W. C. Hagel and H. J. Beattie, Jr.: Trans. Am. Soc. Met., 49 (1957), 978.

106) D. H. Jack and K. H. Jack: J. Iron Steel Inst., 210 (1970), 790.

107) R Ayer, C. F. Klein and C. N. Marzinsky: Metall. Trans. A, 23A (1992,), 2455.

108) H. Brandis and E. Horn: DEW-Technische Berichte (Germany), 9 (1969), 213.

109) H. J. Goldschmidt: J. Iron Steel Inst., 209 (1971), 900.

110) H. J. Goldschmidt: J. Iron Steel Inst., 209 (1971), 910.

111) J. R. Donati, D. Guttmann and G. Zacharie: Rev. Métall., Cah. Inf. Tech., 71 (1974), 917.

112) A. F. Padilha and G. Schanz: J. Nucl. Mater., 95 (1980), 229

113) X. X. Yao: Mater. Sci. Eng. A, A271 (1999), 353.

114) H. Kaneko, T. Nishizawa and K. Tamaki: J. Jpn. Inst. Met., 27 (1963), 299.

115) C. Da Casa and V. B. Nileshwar: J. Iron Steel Inst., 207 (1969), 1003.

116) Y. Mandiang and G. Cizeron: Mater. Sci. Eng. A, A206 (1996), 233.

117) M. G. Gemmill, H. Hughes, J. D. Murray, F. B. Pickering and K. W. Andrews: J. Iron Steel Inst., 184 (1956), 122.

118) J. F. Brown, W. D. Clark and A. Parker: Metallurgia, 56 (1957), 215.

119) C. Frick and H. Rhode: Arch. Eisenhüttenwes., 31 (1960), 419.

120) H. Kudielka and H. Rhode: Z. Kristallogr., 114 (1960), 447.

121) E. S. Davenport and E. C. Bain: Trans. Am. Inst. Mining Met. Eng., 90 (1930), 117.

122) R. E. Schramm and R. P. Reed: Metall. Trans. A, 6A (1975), 1345.

123) C. G. Rhodes and A. W. Thompson: Metall. Trans. A, 8A (1977), 1901.

124) W. Reick, M. Pohl and A. F. Padilha: Steel Res., 67 (1996), 253.

125) J. M. Silcock, R. W. Rookes and J. Barford: J. Iron Steel Inst., 204 (1966), 623.

126) A. F. Padilha, J. C. Dutra and V. Randle: Mater. Sci. Technol., 15 (1999), 1009.

127) S. M. Box and F. G. Wilson: J. Iron Steel Inst., 210 (1972), 718.

128) W. Kesternich and D. Meertens: Acta Metall., 34 (1986), 1071.

129) G. Lennartz: Mikrochim. Acta, Hefte 3 (1965), 405.

130) P. Rozenak, L. Zevin and D. Eliezer: J. Mater. Sci., 19 (1984), 567.

131) D. J. Dyson and B. Holmes: J. Iron Steel Inst., 208 (1970), 469.

132) G. J. Eichelmann and F. C. Hull: Trans. Am. Soc. Met., 45 (1953), 77.

133) E. P. Butler and M. G. Burke: Acta Metall., 34 (1986), 557.

134) M. W. Bowkett, S. R. Keown and D. R. Harries: Met. Sci., 16 (1982), 499.

135) P. Marshall: Austenitic Stainless Steels: Microstructure and Mechanical Properties, Elsevier Applied Science Publishers Ltd., New York, (1984), 23.

136) Y. Kaieda and A. Oguchi: J. Mater. Sci., 20 (1985), 1847

137) T. J. Angel: J. Iron Steel Inst., 177 (1954), 1654.

138) P. L. Mongonon, Jr. and G. Thomas: Metall. Trans. A, 1A (1970), 1577.

139) P. L. Mongonon, Jr. and G. Thomas: Metall. Trans. A, 1A (1970), 1587.

140) V. Seetharaman and R. Krishnan: J. Mater. Sci., 16 (1981), 523.

141) L. F. M. Martins, R. L. Plaut and A. F. Padilha: ISIJ Int., 38 (1998), 572.

142) S. F. Peterson, M. C. Mataya and D. K. Matlock: JOM, 49 (1997), No. $9,54$.

143) V. Taylan, R. H. Wagoner and J. K. Lee: Metall. Mater. Trans. A, 29A (1998), 2161.

144) G. T. Burstein, I. M. Hutchings and K. Sasaki: Nature, 407 (2000), 885 . 